\title{
International Journal of Earth Sciences
}

\section{The Late Neoproterozoic magmatism in the metasedimentary Ediacaran series of the Eastern Pyrenees: New ages and isotope geochemistry \\ --Manuscript Draft--}

\begin{tabular}{|c|c|}
\hline \multicolumn{2}{|l|}{ Manuscript Number: } \\
\hline Full Title: & $\begin{array}{l}\text { The Late Neoproterozoic magmatism in the metasedimentary Ediacaran series of the } \\
\text { Eastern Pyrenees: New ages and isotope geochemistry }\end{array}$ \\
\hline Article Type: & Original Paper \\
\hline Keywords: & $\begin{array}{l}\text { U-Pb zircon geochronology: Sr-Nd isotopes; Ediacaran magmatism; Cadomian; } \\
\text { Pyrenees }\end{array}$ \\
\hline Corresponding Author: & $\begin{array}{l}\text { Josep Maria Casas } \\
\text { Universitat de Barcelona } \\
\text { Barcelona, SPAIN }\end{array}$ \\
\hline \multicolumn{2}{|l|}{$\begin{array}{l}\text { Corresponding Author Secondary } \\
\text { Information: }\end{array}$} \\
\hline Corresponding Author's Institution: & Universitat de Barcelona \\
\hline \multicolumn{2}{|l|}{$\begin{array}{l}\text { Corresponding Author's Secondary } \\
\text { Institution: }\end{array}$} \\
\hline First Author: & Josep Maria Casas \\
\hline \multicolumn{2}{|l|}{ First Author Secondary Information: } \\
\hline \multirow[t]{9}{*}{ Order of Authors: } & Josep Maria Casas \\
\hline & Marina Navidad \\
\hline & Pedro Castiñeiras \\
\hline & Montserrat Liesa \\
\hline & Carmen Aguilar \\
\hline & Jordi Carreras \\
\hline & Mandy Hofmann \\
\hline & Andreas Gärtner \\
\hline & Ulf Linnemann \\
\hline \multicolumn{2}{|c|}{ Order of Authors Secondary Information: } \\
\hline Abstract: & $\begin{array}{l}\text { Geochronological U-Pb (LA-ICP-MS), geochemical and isotopic data from } \\
\text { metavolcanic felsic rocks of the Canigó and Cap de Creus massifs in the Eastern } \\
\text { Pyrenees provide evidence of an Ediacaran magmatic event lasting } 30 \text { m.y. in NE } \\
\text { Iberia. Data also constrain the age of the Late Neoproterozoic succession in the Cap } \\
\text { de Creus massif, where depositional ages range from } 577 \text { to } 558 \mathrm{Ma} \text {, and in the } \\
\text { Canigó massif, where the data ( } 575 \text { to } 568 \mathrm{Ma} \text { ) represent minimum ages. } \\
\text { Geochemistry indicates that the rocks were formed in a back-arc environment and } \\
\text { record a fragment of a long-lived subduction-related magmatic arc ( } 620 \text { to } 520 \mathrm{Ma} \text { ) in } \\
\text { the active northern Gondwana margin. The homogeneity shown by all these crustal } \\
\text { fragments along this margin suggests that the individualization of the Pyrenean } \\
\text { basement from the Iberian Massif started later, probably during its transition from an } \\
\text { active to a passive margin in Cambro-Ordovician times. }\end{array}$ \\
\hline
\end{tabular}


1 The Late Neoproterozoic magmatism in the metasedimentary Ediacaran series of the

4 J.M. Casas ${ }^{1, *}$, M. Navidad ${ }^{2}$, P. Castiñeiras ${ }^{2}$, M. Liesa ${ }^{3}$, C. Aguilar ${ }^{3}$, J. Carreras ${ }^{4}$, M. 5 Hofmann $^{5}$, A. Gärtner ${ }^{5}$, U. Linnemann ${ }^{5}$

6

$7 \quad{ }^{1}$ Departament de Geodinàmica i Geofísica-Institut de recerca GEOMODELS

8 Universitat de Barcelona, Martí i Franquès s/n, Barcelona, 08028, Spain.

$9 \quad{ }^{2}$ Departamento de Petrología y Geoquímica, Universidad Complutense de Madrid. 28040 10 Madrid, Spain.

$11 \quad{ }^{3}$ Departament de Geoquímica, Petrologia i Prospecció Geològica

12 Universitat de Barcelona, Martí i Franquès s/n, Barcelona, 08028, Spain.

$13{ }^{4}$ Departament de Geologia, Universitat Autònoma de Barcelona, Bellaterra (Cerdanyola del 14 Vallès), 08193, Spain.

$15{ }^{5}$ Senckenberg Naturhistorische Sammlungen Dresden, Museum für Mineralogie und 16 Geologie, Sektion Geochronologie. Königsbrücker Landstraße 159, D-01109 Dresden, 17 Germany

18

19 Abstract Geochronological U-Pb (LA-ICP-MS), geochemical and isotopic data from metavolcanic felsic rocks of the Canigó and Cap de Creus massifs in the Eastern Pyrenees

21 provide evidence of an Ediacaran magmatic event lasting 30 m.y. in NE Iberia. Data also 22 constrain the age of the Late Neoproterozoic succession in the Cap de Creus massif, where 23 depositional ages range from 577 to $558 \mathrm{Ma}$, and in the Canigó massif, where the data (575 to $24568 \mathrm{Ma}$ ) represent minimum ages. Geochemistry indicates that the rocks were formed in a back-arc environment and record a fragment of a long-lived subduction-related magmatic arc (620 to $520 \mathrm{Ma}$ ) in the active northern Gondwana margin. The homogeneity shown by all 
27 these crustal fragments along this margin suggests that the individualization of the Pyrenean

28 basement from the Iberian Massif started later, probably during its transition from an active to

29 a passive margin in Cambro-Ordovician times.

30

31 Keywords U-Pb zircon geochronology, Sr-Nd isotopes, Ediacaran magmatism, Cadomian, 32 Pyrenees

33

34 *Corresponding author. Tel.: +34 934021388; fax: +34 93401340

35 E-mail address: casas@ub.edu (J.M. Casas)

36

\section{Introduction}

38

39 Late Neoproterozoic-Early Cambrian magmatic rocks have been extensively described in the

40 Ediacaran sequences of several areas of the European Variscan Belt (Lescuyer and Cocherie 41 1992; Fernández-Suárez et al. 1998; Alexandrov et al. 2001; Gutiérrez-Alonso et al. 2004;

42 Mingram et al. 2004; Teipel at al. 2004; Alexandre 2007; Melleton et al. 2010; Rubio43 Ordóñez et al. 2013) and in the Variscan basement rocks involved in the Mediterranean 44 Alpine orogens (Cocherie et al. 2005; Micheletti et al. 2007; Castiñeiras et al. 2008; Williams 45 et al. 2012; Fiannacca et al. 2013). These magmatic rocks, which constitute the most important evidence of the Cadomian orogeny in these areas, are associated with the later

47 stages of the long-lived active margin that resulted from a Gondwana directed subduction of a 48 former (Protothetys or Iapetus?) peri-Gondwanan ocean. These rocks also provide valuable 49 information about the northern continental margin of Gondwana during its transition from 50 active to passive in Cambro-Ordovician times (Eguiluz et al. 2000; Nebauer 2002; Murphy et 51 al. 2004; Simancas et al. 2004; Linnemann et al. 2007; Nance et al. 2010). In most cases, the geochemical and isotopic studies of these igneous rocks enable us to assess the age of the pre- 
53 Ordovician metasedimentary sequences and correlate them along the whole margin. Should

54 these studies not be undertaken, the ages of these sequences would remain unresolved because

55 of the intensity of the Variscan and/or the Alpine deformation and metamorphism, the lack of

56 fossiliferous content and the absence of reference stratigraphic horizons (Gutiérrez-Alonso et

57 al. 2004; Rodríguez-Alonso et al. 2004; Talavera et al. 2012). This is the case of the basement

58 of the Pyrenees, where Ediacaran magmatic rocks are interbedded in or intrude into a thick

59 pre-Silurian series and constitute the only age constraint for the lower segment of this

60 sequence (Cocherie et al. 2005; Castiñeiras et al. 2008; Mezger 2010). This pre-Silurian

61 material exhibits characteristics that hamper their correlation with the classic zones defined in

62 the Iberian Massif, suggesting a different evolution during Ordovician times. In the Pyrenees,

63 we can highlight the absence of a thick Early Ordovician detrital sequence, the presence of

64 Late Ordovician magmatism and the evidence of Ordovician deformation (see discussion in

65 Navidad et al. 2010). These characteristics pose some interesting questions about when this

66 divergent evolution started and about the position of the Ediacaran rocks of the Pyrenees in

67 the Gondwana margin.

68

In order to discuss these topics, we present new geochemical, isotopic and

69

75

geochronological data from Late Neoproterozoic magmatic rocks of the Canigó and Cap de Creus massifs of the Eastern Pyrenees. These data allow us to characterize the pre-Variscan geodynamic evolution of this segment of the northern Gondwana margin and could help us to understand the paleogeography of the northern margin of Gondwana in Ediacaran times.

\section{Geological setting}

The presence of pre-Variscan igneous rocks in the pre-Silurian basement rocks of the Pyrenees have been reported by Guitard and Laffitte (1956) and Cavet (1957). These authors described metavolcanic acid rocks with a porphyritic texture, known as gneiss granulé 
(granular gneiss). These rocks are located in the lower part of a thick (up to 5000? $\mathrm{m}$ ) unfossiliferous metasedimentary series. This series is composed of metapelites and

81 metagreywackes and interbedded with numerous layers of marbles, quartzites and calcsilicates and is cut by orthogneiss bodies. In the Canigó massif (Fig. 1), Guitard (1970), Casas et al. (1986), Ayora and Casas (1986) and Navidad and Carreras (2002) also described greenschists and amphibolites derived from basaltic lava flows, diabasic dikes and gabbro bodies mainly located in the middle and lower part of this succession (Fig. 2). The close location of metavolcanic acid and basic rocks indicate that this bimodal magmatism may be coeval. The age of this lower series in the Canigó massif has been obtained by analyzing the U-Pb system in zircon by SHRIMP (Cocherie et al. 2005; Castiñeiras et al. 2008). However, the amount of inherited zircon hampers a straightforward interpretation of the isotopic data, resulting in two contrasting ages of 581 and $560 \mathrm{Ma}$, respectively (Fig. 2 and 3a) (Table 1). In addition, several bodies of augen orthogneisses (up to $2000 \mathrm{~m}$ thick) derived from Ordovician intrusives (Cocherie et al. 2005; Casas et al. 2010) are present in this lower part of the succession. In the neighboring Roc de Frausa massif (Fig. 1), metatuffs have been assigned a Late Neoproterozoic age (548 $\pm 8 \mathrm{Ma}$, SHRIMP U-Pb in zircon Castiñeiras et al. 2008) for the uppermost part of the succession. The Mas Blanc orthogneiss located in the lower part of the

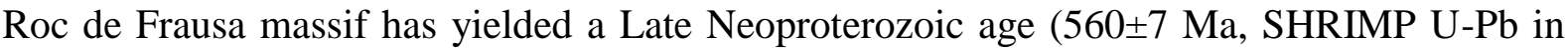
zircon, Castiñeiras et al. (2008). Nevertheless, because of its intrusive character, it cannot be used to determine the age of the lowermost part of the series since it only provides a minimum depositional age. This succession is overlain by a rhythmic alternation of sandstones, siltstones and argillites, $1500 \mathrm{~m}$ thick, with no metavolcanic intercalations (Fig. 101 2). This upper segment was recently dated using an acritarch assemblage that yielded a Late 102 Cambrian (Furongian) to Early Ordovician age (Casas and Palacios 2012). In contrast, the Cap de Creus massif is mainly made up of a 1000 m thick monotonous 104 alternation of predominant greywackes, with subordinate pelites and discontinuous layers of 
plagio-amphibolites, banded quartzites and marbles that correspond to the lower segment of

106 the pre-Silurian sequence. Metabasites crop out at the bottom and in the middle part of this

107 sequence whereas metatuffs are mainly interstratified at the top (Fig. 2 and 3b) (Navidad and

108 Carreras 1995). Metabasites proceed from gabbro-dolerite intrusions and basaltic lens-shaped

109 bodies, and metatuffs derive from Al-rich calc-alkaline rhyolites and rhyodacites (Navidad

110 and Carreras 1995). Metatuffs are interbedded with carbonaceous black slates and marbles.

111 They yielded a Late Neoproterozoic age (560 $\pm 10 \mathrm{Ma}$, SHRIMP U-Pb in zircon, Castiñeiras et

112 al. 2008) (Table 1). The uppermost outcropping levels are conglomerates, siliciclastic

113 sediments and carbonates with marked lateral changes (Losantos et al. 1997). In contrast with

114 the Canigó massif, no large aluminous augen ortthogneiss bodies derived from Ordovician

115 intrusives are present, and only a $200 \mathrm{~m}$ thick sub-aluminous subvolcanic orthogneiss body

116 (the so-called Port gneiss, Carreras and Ramírez 1984) crops out at the bottom of the

117 sequence. Its protolith corresponds to a small intrusion of quartz-monzonite that yielded

$118553 \pm 4.4 \mathrm{Ma}$ (SHRIMP U-Pb in zircon Castiñeiras et al. 2008) (Table 1). Thus, the Port gneiss

119 can be regarded as the plutonic equivalent of the metavolcanic rocks located in the upper part

120 of the sequence.

A well-dated Upper Ordovician succession (Cavet 1957; Hartevelt 1970) lies

122 unconformably over the former sequences (Santanach 1972a; García-Sansegundo and Alonso

123 1989; Den Brok 1989; Kriegsman et al. 1989; Casas and Fernández 2007) (Fig. 3a). Although

124 it is not easy to evaluate the magnitude of this unconformity, it may be assumed that there

125 was considerable erosion before the Upper Ordovician deposition, because Upper Ordovician

126 rocks overlie different sections of the pre-Upper Ordovician succession in the Central and

127 Eastern Pyrenees (Santanach 1972a; Laumonier and Guitard 1986; Cirés et al. 1994; Muñoz

128 et al. 1994). During the Silurian, black shales were deposited, which grade upwards to

129 alternating black limestones and shales. The Devonian is represented by a limestone

130 sequence, whereas the Carboniferous is made up of a detrital sequence (Culm facies) 
composed of slates with sandstones and conglomerates that unconformably overlie the

132 aforementioned sequence.

Variscan deformation (Late Visean to Serpukhovian) accompanied by hightemperature-low-pressure metamorphism affected all these sequences (Guitard 1970; Zwart 1979). Syn to late orogenic granitoids (Late Bashkirian-Kasimovian, Romer and Soler 1995; Maurel 2003; Aguilar et al. 2013 and references therein) intruded mainly into the upper levels of the succession. It should be noted that in the Pyrenees no tectono-metamorphic event related to the Cadomian orogeny has been described hitherto and that only a weakly developed Ordovician deformation (Mid? to Late Ordovician in age) has been reported (Casas 2010), giving rise to folds without cleavage development and to normal faults. Finally, the Alpine cycle did not lead to a considerable penetrative deformation in the Variscan basement rocks (Muñoz 1992).

\section{Sampling rationale}

146 As stated above, the age of the lower sequence in the Canigó massif is only constrained by

147 radiometric data although the two $\mathrm{U}-\mathrm{Pb}$ studies in zircon have yielded different ages. In order 148 to better constrain the age of the interbedded volcanism and therefore the age of this 149 succession, we selected three samples of acid metavolcanic rocks of the middle part of the series and three samples of metabasites of the lower part of the series on the southern slope of

151 the massif (Fig. 2 and 3a). Using the standard separation methods, only the acid metavolcanic 152 rocks yield zircons and thus the age of the lowermost part of the succession remains 153 unresolved.

Samples TG-07-01, TG-7-02 and TG-07-03 correspond to feldspathic ignimbrites collected near Tregurà in an area where the metavolcanic rocks attain their maximum 
158 (Figs. 2 and 3a). They are formed by heterometric rock fragments mostly of volcanic origin 159 and minor bedrock fragments (limestones and greywackes) from $3-5 \mathrm{~cm}$ in size. The matrix is 160 granular to mud-size with crystal fragments of feldspar and quartz resembling gneiss granulé. 161 These rocks are interbedded with other sedimentary rocks, including black shales, sandstones and limestones and have been previously described as conglomerates (Cirés et al. 1994). However, it is possible to detect, at outcrop and thin section scales, ample evidence of their volcanic origin. Sample TG-07-01 corresponds to an ignimbrite of andesitic-dacitic composition. It is a heterogeneous rock formed by elongated rock fragments in a groundmass with millimetric feldspars. It is formed by plagioclase and quartz porphyroclasts in a foliated microcrystalline matrix. Plagioclase is subidiomorphic to xenomorphic, and quartz is rounded and embayed. The matrix is heterogeneous with varying mineral contents in different areas, suggesting that it was originally formed by rock fragments. However, deformation has blurred

170 the limits of the rock fragments, hampering their distinction. In some cases, the matrix is 171 composed of quartz, feldspar, phengitic muscovite, chlorite and calcite. Zircon and ilmenite 172 are the main accessory minerals. Replacements of K-feldspar by albite and myrmekitic quartz 173 are frequent. Leucoxene, and locally titanite, replace ilmenite. Leucoxene is generally 174 associated with calcite. Two foliations can be observed, defined by secondary muscovite, 175 chlorite and iron ore. The first foliation is folded, forming a well-developed axial plane 176 foliation. Calcite crystallizes as plates in the matrix and in pressure shadows around 177 plagioclase porphyroclasts. Sample TG-07-02 corresponds to an andesitic-dacitic ignimbrite 178 alternating with ampelitic black layers. Feldspar and quartz porphyroclasts (1-2 mm in size) 179 are embedded in a fine-grained foliated recrystallized groundmass made up of quartz, 180 feldspar, chlorite, calcite and white mica with leucoxene and clinozoisite as accessory 181 minerals. The groundmass exhibits shards recrystallized to sericite. Quartz porphyroclasts are 182 locally embayed and formed by subgrains. Sample TG-07-03 is an andesitic ignimbrite 
similar to the samples described above. Under the microscope, it presents plagioclase and

184 quartz porphyroclasts in a fine-grained recrystallized groundmass formed by aggregates of 185 roughly equidimensional quartz and feldspar. Rounded and embayed quartz is usually broken 186 and cemented by the matrix. Abundant ignimbrite textures are present in the matrix, such as 187 glass shards and glass spherulitic textures replaced by leucoxene.

In the Cap de Creus massif, three acid metavolcanic rocks and three metabasites were sampled for $\mathrm{U}-\mathrm{Pb}$ zircon analysis in order to determine the age of the bimodal magmatism and to better constrain the age of the Ediacaran sequence in this massif (Figs. 2 and $3 \mathrm{~b}$ ). 191 Again, no zircon was detected in the metabasites. Sample CC-08-01 corresponds to a decimeter sized metatuff located at the bottom of the sequence, whereas samples CC-08-07 and CC-08-08 are metatuffs located on top of the succession (Fig. 2). Sample CC-08-01 is a very fine-grained amphibolic leucogneiss. It corresponds to an ash tuff or lava of trachyandesitic composition. The metamorphic mineral assemblage is quartz, albite and white mica, estilpnomelane and scarce green amphibol (edenitic hornblende) with zircon, tourmaline, leucoxene and iron ore as accessory minerals. It has a porphyroclastic texture with a grano-lepidoblastic groundmass. Quartz and feldspar (mostly plagioclase) porphyroclasts range between $0,1-0,2 \mathrm{~mm}$ in size. They have a rounded 200 to elongated shape with crystal faces. Polysynthetic twinning is abundant in plagioclase and 201 some feldspars also present Carlsbad twinning. Porphyroclasts are wrapped by white mica 202 defining the main foliation. Sample CC-08-07 corresponds to an andesitic metatuff with porphyroclastic texture and a grano-lepidoblastic matrix. Porphyroclasts are scarce and are 204 mainly formed by plagioclase. They are between $0,2-0,3 \mathrm{~mm}$ in size, though some crystals 205 attain $1 \mathrm{~mm}$. The groundmass is grano-lepidoblastic and is composed of quartz, white mica, 206 actinolite, chlorite, titanite and calcite. Plagioclase is partly replaced by clinozoisite. 207 Muscovite defines a foliation. Ignimbritic textures are recognized as shards and flames recrystallized to sericite. Sample CC-08-08 corresponds to a metatuff of basaltic andesite 
composition. It has a porphyroclastic texture in a very fine-grained groundmass. The

210 metamorphic mineral assemblage is formed by quartz, albite and chlorite with leucoxene,

211 zircon and ilmenite as accessory minerals. Porphyroclasts (up to $2 \mathrm{~mm}$ in size) are composed 212 of quartz and of plagioclase with polysynthetic twinning fragmented and welded by the

213 matrix. The groundmass is formed by recrystallized quartz and feldspar and by newly formed

214 metamorphic chlorite exhibiting a preferred orientation. Chlorite also crystallizes in pressure

215 shadows around the porphyroclasts.

\section{Results}

Whole-rock geochemistry

221 Whole-rock analyses were carried using ICP-OES (Inductively Coupled Plasma-Optical 222 Emission Spectrometry) for major and minor elements, and ICP-MS (Inductively Coupled 223 Plasma-Mass Spectrometry) for trace elements at the Spectrochemical Laboratory of the

224 Centre de Recherches en Pétrographie et Géochimie of Nancy (France). See Online Resource 2251 for analytical details. Results are given in Table 2.

Acid porphyroclastic tuffs and ashes have been classified using conventional diagrams 227 for presumably modified rocks based on trace elements, such as $\mathrm{Zr} / \mathrm{Ti} \mathrm{vs}$. $\mathrm{Nb} / \mathrm{Y}$ (Winchester and Floyd 1977) and Th vs. Co (Hastie et al. 2007) (Fig. 4). Most of the samples cluster along the line between the andesite and dacite-rhyodacite fields (Fig. 4a) or inside the dacite230 rhyolite (Fig. 4b), depending on the diagram used. In the Hastie et al. (2007) diagram, the 231 samples also plot in the high K calc-alkaline domain.

A trace element diagram normalized to the ORG (Harris et al. 1986) is presented in 233 Fig. 5a. All the samples show similar profiles characterized by an enrichment of the mobile 234 elements $(\mathrm{K}, \mathrm{Rb}, \mathrm{Ba}, \mathrm{Th}$, excepting sample $\mathrm{CC}-08-08)$, a negative $\mathrm{Ta}-\mathrm{Nb}$ anomaly and a 
positive $\mathrm{Ce}$ and $\mathrm{Sm}$ anomalies. They also show a relative enrichment of the transition

236 elements with respect to the immobile elements. These patterns are characteristic of the calc-

237 alkaline and shoshonite series in volcanic arcs (Pearce et al. 1984).

In a REE chondrite normalized (Taylor and McLennan 1985) diagram (Fig. 5b), the patterns are very similar. All the samples are enriched in light REE (LREE) with respect to the heavy REE (HREE), and show a moderate fractionation (with LREE/HREE ratios

241 between 6.5 and 11) and a slight negative Eu anomaly ( $\mathrm{Eu} / \mathrm{Eu}^{*}$ between 0.52 and 0.65$)$. These

242 patterns are typical of calc-alkaline rocks with plagioclase fractionation and without the 243 participation of garnet. In the Cap de Creus samples, it is important to note that CC-08-01 and

244 CC-08-07 (amphibole-bearing tuffs) are more depleted in total REE ( $\square$ REE=165 and 119, 245 respectively) than CC-08-08, a non amphibolic ignimbrite with $\square \mathrm{REE}=246$.

246 As regards the geodynamic setting (Fig. 6), most of the samples plot between the

247 volcanic arc and the within-plate fields in a Hf-Rb/30-Tax3 diagram (Harris et al. 1986).

Isotopic geochemistry

251 Sr-Nd isotope analyses were performed at the Geochronology and Isotope Geochemistry 252 Centre of the Complutense University (Madrid, Spain) using ID-TIMS in a sector 54 VG-

253 Micromass Multicollector Spectrometer. Details of the analytical procedures are given in the

254 Online Resource 1. The Sr-Nd isotope results are shown in Table 3.

Most of the samples show a relatively homogeneous ${ }^{87} \mathrm{Sr} /{ }^{86} \mathrm{Sr}$ isotopic content with 256 ratios between 0.704474 and 0.709730 . The lowest value in sample TG-07-01 probably 257 represents a disturbance of the $\mathrm{Rb}$-Sr isotopic system, whereas the maximum value in sample 258 CC-08-08 could be related to crustal contamination. In contrast, the ${ }^{143} \mathrm{Nd} /{ }^{144} \mathrm{Nd}$ ratios are 259 more uniform, varying between 0.511679 and 0.511884 . For the epsilon notation, all samples 260 were normalized to an age of $560 \mathrm{Ma}$. The $\square \mathrm{Nd}$ values were moderately enriched for most of 
the samples (below -4.0), with the exception of sample CC-08-01, which had a less enriched

262 value of -0.6 (Fig. 7a, Table 3). In the $\square$ Sr- $\square$ Nd diagram (Fig. 7b), it should be noted that the

263 variability observed in the Cap de Creus between sample CC-08-01 and sample CC-08-08, in

264 the $\mathrm{Sr}$ and the $\mathrm{Nd}$ systems is compatible with a fractionation and a variable crustal 265 contamination of juvenile mantle-derived melts (Navidad and Carreras 1995). Alternatively, 266 the Canigó samples (excepting sample TG-07-01) plot in a narrow area of the young 267 continental crust field.

Zircon geochronology

271 The volcaniclastic nature of the analyzed samples gives rise to a large amount of inherited 272 and/or detrital zircon, ruling out the possibility of precise dating of these rocks in the Canigó 273 massif (Cocherie et al. 2005; Castiñeiras et al. 2008). To overcome this problem, we use the 274 LA-ICP-MS technique (Laser Ablation, Inductively Coupled Plasma, Mass Spectrometry) to 275 analyze the $\mathrm{U}, \mathrm{Th}$, and $\mathrm{Pb}$ isotopes in zircon since we can obtain more data much faster than 276 with the SHRIMP. The analyses were carried out at the Museum für Mineralogie und 277 Geologie (Senckenberg Naturhistorische Sammlungen Dresden), using a Thermo-Scientific 278 Element 2 XR sector field ICP-MS coupled to a New Wave UP-193 Excimer laser system.

279 Details of the analytical procedure and the results of the zircon analyses are shown in Online $280 \quad$ Resource 1 and 2.

Under cathodoluminescence (CL), most zircons from the Canigó samples exhibit 282 oscillatory zoning, with scarce xenocrystic cores or metamorphic rims. Some zircon grains 283 with homogeneous textures can be found (Fig. 8). We carried out a total of 184 analyses in as 284 many zircon grains from the three Canigó samples selected. We disregarded 22 analyses with 285 discordance higher than $10 \%$. In spite of our efforts to avoid inheritance during the hand picking of the zircon grains (see analytical procedure in SD-1), the remaining 162 analyses 
are dispersed between 546 and 2,640 Ma. Taking into account previous works (Cocherie et al.

288 2005; Castiñeiras et al. 2008), we selected the analyses younger than 590 Ma to calculate the

289 crystallization ages using the statistical methods available in Isoplot (Ludwig 2001), whereas 290 older data were considered inheritance.

In sample TG-07-01, eleven analyses vary between 555 and $588 \mathrm{Ma}$, yielding a concordia age (sensu Ludwig 1998) of 570 \pm 5 Ma (Fig. 9a), with a mean square of weighted deviation (MSWD) of 0.43. In sample TG-07-02, nine analyses vary between 546 and 587 Ma, yielding a concordia age of 568 \pm 6 Ma, with an MSWD of 0.0056 (Fig. 9b). Twenty analyses from sample TG-07-03 vary between 564 and 588 Ma, yielding a concordia age of 575 \pm 4 , with an MSDW of 0.15 (Fig. 9c).

We performed 380 analyses in zircon grains from the three Cap de Creus samples selected. We rejected 101 analyses with discordance higher than 10\%. The inherited component in these samples is also significant, and the resulting ages vary between 543 and 2,554 Ma. As in the previous sample, we selected the analyses younger than $590 \mathrm{Ma}$ to extract the crystallization ages, whereas older data were regarded as inheritance. In accordance with their volcano-sedimentary origin, zircons from the Cap de Creus samples display an assortment of textures under CL (Fig. 8). These textures include abundant core-rim

304 features with variable luminescence, where cores represent xenocrysts and are surrounded by 305 oscillatory rims of magmatic origin. Other textures comprise some homogeneous and scarce sector zoning.

In sample CC-08-01, twelve analyses vary between 568 and $590 \mathrm{Ma}$, yielding a

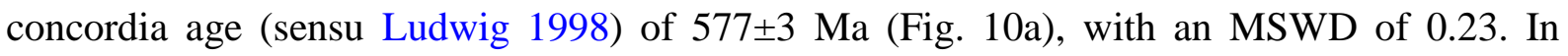
309 sample CC-08-07, twenty-two analyses vary between 543 and 590 Ma, yielding a concordia 310 age of $571 \pm 5 \mathrm{Ma}$ (Fig. 10b). However, the high mean square of weighted deviation $311(\mathrm{MSWD}=10)$ suggests that more than one age population is included in this concordant 312 dataset. For this reason, we use the Sambridge and Compston (1994) statistical approach to 
extract these age populations. Thus, two classes can be established, namely an older age of

$314580 \mathrm{Ma}$ and a younger age of $561 \mathrm{Ma}$ (Fig. 10c). To decide between these two possible ages,

315 we go back to the cathodoluminescence images, where we can observe the disparity of CL

316 textures in the oldest spots, whereas the areas that yielded the youngest ages show similar CL

317 characteristics. Thus, we obtain the crystallization age of the rock pooling together the

318 fourteen youngest analyses (Fig. 10b), which is $563 \pm 5$ Ma (MSWD=4.2). Finally, twenty-

319 seven analyses from sample CC-08-08 vary between 539 and 579 Ma, yielding a concordia

320 age of 558 \pm 3 , with an MSDW of 2.8 (Fig. 10d).

322 Discussion

324 Petrogenesis, tectonic setting and age

The homogeneous patterns shown in the ORG-normalized trace element and in the chondritenormalized REE diagrams suggest that all the samples were formed in the same tectonic setting. Furthermore, the high potassium content, the relative enrichment in large ion lithophile elements associated with high field strength elements and the $\mathrm{Nb}$ - $\mathrm{Ta}$ negative anomaly indicate that this setting was an active continental margin. However, the whole-rock and isotope geochemistry of the samples reveal a subtle 332 difference in their petrogenesis. On the one hand, the enrichment in $\square \mathrm{Nd}$ in the Canigó 333 samples (TG-07-01, 02 and 03) lends support to our interpretation and highlights the 334 influence of old material. The TDM ages ( 1.5 Ga, Fig. 7a) do not correspond to the ages 335 found hitherto in inherited zircons (Cocherie et al. 2005; Castiñeiras et al. 2008). It should be 336 noted that none of these studies focused on inheritance with result that sampling bias could 337 arise. The $\mathrm{U}-\mathrm{Pb}$ ages obtained from zircon are equivalent within error in all the samples and 338 indicate that the magmatism in the Canigó massif took place around $570 \mathrm{Ma}$. On the other 
339 hand, the Cap de Creus samples (CC-08-01, 07 and 08) show some differences among them,

340 not only in their chemistry and age, but also in their petrography. The presence of amphibole

341 in two samples, the low REE contents and the less enriched $\square \mathrm{Nd}$ values in samples CC-08-01

342 and CC-08-07 suggest an influence of a juvenile source in the origin of these rocks.

343 Furthermore, the trend observed in Fig. $7 \mathrm{~b}$ is interpreted in this work as the result of a

344 combination of fractionation and crustal contamination between a juvenile mantle source and

345 an enriched crust. The ages obtained in these rocks are less homogeneous than in the Canigó,

346 varying between 558 and $577 \mathrm{Ma}$. In addition, the enrichment in $\mathrm{Nd}$ is higher in the youngest

347 samples, i.e. the influence of the juvenile source (probably the mantle) decreased with time.

348 This evolution is compatible both with the closure of an oceanic domain and with the

349 thickening of a previous thinned crust, probably in a back-arc setting. The absence of 350 ophiolites in the Ediacaran section of the Pyrenees and the abundance of coeval mafic lavas 351 interbedded in the Ediacaran series of the Cap de Creus massif (Navidad and Carreras 1995)

352 favor the latter possibility.

With the available data, it is not clear whether the juvenile influence is restricted to the

354 Cap de Creus massif or whether it also affected the magmatism in the Canigó massif. If the 355 former option were correct, both massifs would represent two slightly different scenarios in 356 the active continental margin, a small back-arc basin (Cap de Creus) and a zone with more 357 continental influence (Canigó). Further studies on the influence of a juvenile source are 358 necessary in the Canigó massif to either confirm or reject this interpretation.

An additional contribution of this work is the refinement in the age of the Ediacaran magmatism. The data presented here as well as previous published data provide evidence of 361 an Ediacaran magmatic event lasting 30 m.y. in NE Iberia. In this area, volcanic activity 362 seems to be continuous from 577 to $548 \mathrm{Ma}$, whereas granite production took place between 363560 and 553 Ma. Earlier studies (Cocherie et al. 2005; Castiñeiras et al. 2008) report ages 364 obtained by SHRIMP using a limited amount of data (less than 25 analyses in each work). 
However, the abundance of inherited zircons in these volcaniclastic rocks hampers the

366 interpretation of the preferred age in these studies. In fact, there is a variation of $\sim 20$ m.y.

367 from one work to another. Furthermore, even if the best smoothest zircon grains are selected

368 to avoid detrital or inherited components in areas where a protracted active margin exists, it is

369 not easy to distinguish between zircons formed during the last magmatic event and short-

370 traveled zircons from closer and slightly older domains. In this case, the number of analyses

371 should be increased to obtain a more reliable and representative set of the youngest

372 population, which is interpreted as the age of magmatism. Given its higher velocity when

373 compared with the SHRIMP technique, the LA-ICP-MS is the ideal choice to accomplish the 374 task.

Data also constrain the depositional age of the Late Neoproterozoic succession in the

376 Cap de Creus and Canigó massifs. In the Cap de Creus massif, depositional ages range from

377577 to $558 \mathrm{Ma}$, whereas the age obtained for the metavolcanic rocks of the Canigó massif

378 (575 to $568 \mathrm{Ma}$ ) should be regarded as the minimum because of a thick series cropping out

379 below these rocks in this massif. It should be noted, that these ages were only obtained in

380 felsic rocks and that the age of the protoliths of the metabasites is still unknown. However, we

381 can consider a similar Late Neoproterozoic age for the metabasaltic lava flows interbedded in

382 the lower part of the succession although the protolith age of the plutonic metabasites remains

383 to be resolved and a younger pre-Variscan (Ordovician?) age cannot be ruled out. Further 384 geochemical and geochronological studies are warranted to elucidate this problem.

385

Comparison with neighboring areas

388 This magmatism may be part of a longer cycle, as revealed by the distribution of magmatic 389 ages obtained in neighboring areas. In the French Massif Central, a magmatic event ranging

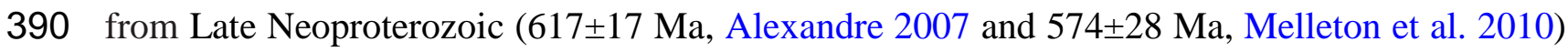




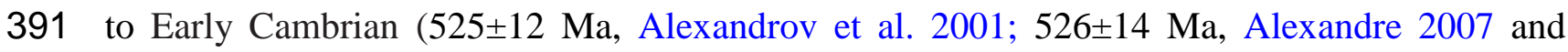

$392529 \pm 4 \mathrm{Ma}$, Melleton et al. 2010) has been described in the metasedimentary successions of the

393 different structural units. On the Montagne Noire, south of the French Massif Central,

394 metavolcanic rocks provided an age of $545 \pm 15$ Ma for the "schistes X" in the uppermost part of

395 the Late Neoproterozoic succession (Lescuyer and Cocherie 1992). These data reinforce the

396 aforementioned correlation between the lowermost series of the Eastern Pyrenees and the

397 Montagne Noire based on lithostratigraphic criteria (Cavet 1957) or on the strong similarities of

398 the metallogenic assemblages (Ayora and Casas 1986). In the Iberian Massif, a magmatic cycle

399 of a similar age has been described. In the Narcea Antiform, between the Cantabrian and

400 Western Asturian-Leonese zones, Late Neoproterozoic ages ranging from $605 \pm 10$ Ma to $557 \pm 3$

401 Ma for plutonic and volcanic rocks intruded or interlayered in the Neoproterozoic siliciclastic

402 series have been obtained by Fernandez-Suárez et al. (1998), Gutiérrez-Alonso et al. (2004)

403 and Rubio Ordóñez et al. (2013). In the Ossa Morena zone, Bandrés et al. (2004) describe

404 diorite and granite bodies intruding at 577.6 $\pm 0.6 \mathrm{Ma}$ and $573 \pm 14 \mathrm{Ma}$. All these authors agree

405 that this Late Neoproterozoic-Early Cambrian magmatism is related to a convergent margin

406 setting, which is a subduction-related magmatic arc.

407 A similar situation has been reported in other Mediterranean Variscan realms involved

408 in the Alpine orogens. In the basement rocks of the Calabria-Peloritani Mountains (southern

409 Italy and NE Sicily), Michelletti et al. (2007), Williams et al. (2012) and Fiannacca et al.

410 (2013) describe an important Late Neoproterozoic-Early Cambrian magmatism ranging from

$411565 \pm 5$ to $526 \pm 10$ Ma. From the age of zircon cores Williams et al. (2012) and Fiannacca et al.

412 (2013) propose a proximity between the depositional age of the Neoproterozoic sequences and

413 the age of the plutonic rocks, indicating a short time span between sedimentation and

414 generation of granitic rocks. In the Menderes massif (western Taurides), Zlatkin et al. (2013)

415 describe a similar situation: bimodal Late Neoproterozoic magmatic rocks intruded from

$416550.6 \pm 1.1$ to $544 \mathrm{Ma}$ in a sequence that exhibits a very close sedimentation age from $\sim 570 \mathrm{Ma}$ 
417 to 550 Ma. Finally, in the Late Neoproterozoic basement rocks of the western Pontides, Yilmaz

418 Şahin et al (2013) reported granites with similar ages from 546 \pm 3.9 to $534 \pm 4.7 \mathrm{Ma}$.

419 Given the available geochronological and geochemical data and the results presented

420 in this paper, it may be argued that the studied rocks record a fragment of a long-lived

421 subduction-related magmatic arc (620 to $520 \mathrm{Ma}$ ) in the active northern Gondwana margin.

422 This margin can be recognized in the Variscan belt of western and central Europe.

423 Furthermore, the fragments of Ediacaran rocks recognized in the Mediterranean orogens

424 suggest that the margin can be extended eastwards through the Turkish massif as far as the

425 Iranian and Caucasus Mountains (see discussion in Yilmaz Şahin et al. (2013).

The homogeneity shown by all these crustal fragments along the Gondwana margin

427 indicates that the individualization of the Pyrenean basement with respect to the Iberian Massif

428 would have started later, probably during its transition from an active to a passive margin in

429 Cambro-Ordovician times.

431 Conclusions

433 The geochemistry of felsic metavolcanic rocks in the upper part of the Ediacaran series from

434 the Canigó and Cap de Creus massifs indicates a convergent setting for their origin. In the

435 Cap de Creus massif isotope geochemistry suggests a juvenile influence in their petrogenesis 436 whereas in the Canigó massif the crustal component is more important. The U-Pb ages 437 obtained reveal that this volcanism took place around 570 Ma in the Canigó massif but in Cap 438 de Creus the volcanic event spanned from 558 through $577 \mathrm{Ma}$.

439 The rocks under study display characteristics similar to those of other Cadomian 440 remnants found in the Variscan and Alpine basement, which taken together represent a 441 convergent margin located in northern Gondwana from 620 through 520 Ma. The partition 442 between the Pyrenean domain and the Iberian Massif probably occurred in Cambro- 
443 Ordovician times, when the tectonic setting underwent a transition from an active to a passive

444 margin.

445

446 Acknowledgements This work was funded by projects CGL2010-21298 and Consolider447 Ingenio 2010, under CSD2006-00041 “Topoiberia”.

448

449

450

References

451 Aguilar C, Liesa M, Castiñeiras P, Navidad M (2013) Late Variscan metamorphic and magmatic evolution in the eastern Pyrenees revealed by $\mathrm{U}-\mathrm{Pb}$ age zircon dating. Journal of the Geological Society London. doi:org/10.1144/jgs2012-086.

454 Alexandre P (2007) U-Pb zircon SIMS ages from the French Massif Central and implication for the pre-Variscan tectonic evolution in Western Europe. Comptes Rendus Geoscience 339: 613-621.

457 Alexandrov P, Floc'h J-P, Cuney M, Cheilletz A (2001) Datation U-Pb à la microsonde ionique des zircons de l'unité supérieure de gneiss dans le Sud Limousin, Massif central. Comptes Rendus de l'Académie des Sciences 332: 625-632.

460 Ayora C, Casas JM (1986) Strabound As-Au mineralization in pre-Caradocian rocks form the Vall de Ribes, Eastern Pyrenees, Spain. Mineralium Deposita 21: 278-287.

Bandrés A, Eguíluz L, Pin C, Paquette J. L, Ordóñez B, Le Fèvre B, Ortega LA, Gil Ibarguchi J I (2004) The northern Ossa-Morena Cadomian batholith (Iberian Massif): magmatic arc origin and early evolution. International Journal of Earth Sciences 93: 860-885.

465 Carreras J, Ramírez J (1984) The geological significance of the Port de la Selva Gneisses (Eastern Pyrenees, Spain). IGCP Newsletter 6: 27-31.

467 Carreras J, Druguet E (2013) Illustrated Field Guide to the Geology of Cap de Creus. Servei de Publicacions de la Universitat Autònoma de Barcelona. 
Casas JM (2010) Ordovician deformations in the Pyrenees: new insights into the significance of pre-Variscan ('sardic') tectonics. Geological Magazine 147: 674-689.

471 Casas JM, Martí J, Ayora C (1986) Importance du volcanisme dans la composition lithostratigraphique du Paléozoïque inférieur des Pyrénées catalanes. Comptes Rendus de l'Académie des Sciences 302: 1193-1198.

474 Casas JM, Fernandez O (2007) On the Upper Ordovician unconformity in the Pyrenees: New evidence from the La Cerdanya area. Geologica Acta 5: 193-198.

Casas JM, Castiñeiras P, Navidad M, Liesa M, Carreras J (2010) New insights into the Late Ordovician magmatism in the Eastern Pyrenees: U-Pb SHRIMP zircon data from the

Casas J.M, Palacios T (2012) First age data obtained by Acritarchs in the pre-Upper Ordovician sequences of the Pyrenees: on the Late Cambrian-Early Ordocivian age of the Jujols Series. Comptes Rendus Geosciences 344: 50-56.

482

Castiñeiras P, Navidad M, Liesa M, Carreras J, Casas J.M (2008) U-Pb zircon ages 483 (SHRIMP) for Cadomian and Lower Ordovician magmatism in the Eastern Pyrenees: new insights in the pre-Variscan evolution of the northern Gondwana margin. Tectonophysics 46:, 228-239.

486 Cavet P (1957) Le Paléozoïque de la zone axiale des Pyrénées orientales françaises entre le Roussillon et l'Andorre. Bulletin Service Carte Géologique France 55: 303-518.

Cirés J, Casas JM, Santanach P, Muñoz J.A, Fleta J, Serrat D (1994( Mapa geológico de España (1:50.000): Molló (nº 218). ITGE Madrid, España.

490 Cocherie A, Baudin Th, Autran A, Guerrot C, Fanning C.M, Laumonier B (2005) U-Pb zircon (ID-TIMS and SHRIMP) evidence for the early Ordovician intrusion of metagranites in the late Proterozoic Canaveilles Group of the Pyrenees and the Montagne Noire (France). Bulletin de la Société Géologique de France 176: 269-282. 
DePaolo DJ (1981) Neodymiun isotopes in the Colorado Front range and crust-mantle evolution in the Proterozoic. Nature 291: 193-196.

Den Brok SWJ (1989) Evidence for pre-Variscan deformation in the Lys Caillaouas area, Central Pyrenees, France. Geologie en Mijnbouw 68: 377-380.

Eguiluz L, Gil Ibarguchi JI, Ábalos B, Apraiz A (2000) Superposed Hercynian and Cadomian orogenic cycles in the Ossa-Morena zone and related areas of the Iberian Massif. Geological Society of America Bulletin 112: 1398-1413. doi: 10.1130/0016-

Fernández-Suárez J, Gutiérrez Alonso G, Jenner G, Simon EJ (1998) Geochronology and 503 geochemistry of the Pola de Allande granitoids (northern Spain): their bearing on the Cadomian-Avalonian evolution of northwest Iberia. Canadian Journal of Earth Sciences 35: 1439-1453.

506 Fiannacca P, Williams IS, Cirrincione R, Pezzino A (2013) The augen gneisses of the 507 Peloritani Mountains (NE Sicily): Granitoid magma production during rapid evolution of the northern Gondwana margin at the end of the Precambrian. Gondwana Research 23: 782-796. doi: 10.1016/j.gr.2012.05.019

García-Sansegundo J, Alonso JL, (1989) Stratigraphy and structure of the southeastern Garona Dome. Geodinamica Acta 3: 127-134.

513 Canigou (Pyrénées orientales). Mémoires du B.R.G.M. 63.

514 Guitard G, Laffitte F, (1956) Sur l'importance et la nature des manifestations volcaniques dans le Paléozoïque des Pyrénées Orientales. Comptes Rendus de l'Académie des Sciences 242: 2749-2752.

Gutiérrez-Alonso G, Fernández-Suárez J, Jeffries TE (2004) Age and setting of the Upper Neoproterozoic Narcea Antiform volcanic rocks. Geogaceta 25: 79-82. 
Harris NBW, Pearce JA, Tindle AG (1986) Geochemical characteristics of collision-zone magmatism. In: Coward, M.P. and Ries, A.C. (Eds.), Collision tectonics. Geological Society Special Publication 19: 67-81.

522

523

524

525

526

527

528

529

530

531

532

533

534

535

536

537

538

539

540

541

542

543

544

Hastie AR, Kerr AC, Pearce JA, Mitchell SF (2007) Classification of altered volcanic island arc rocks using immobile trace elements: Development of the Th-Co discrimination diagram. Journal of Petrology 48: 2341-2357. doi:10.1093/petrology/egm062

Hartevelt JJA (1970) Geology of the upper Segre and Valira valleys, central Pyrenees, Andorra/Spain. Leidse Geologische Mededelingen 45: 167-236.

Kriegsman LM, Aerden DGAM, Bakker RJ, den Brok SWJ, Schutjens PMTM (1989) Variscan tectonometamorphic evolution of the eastern Lys- Caillaouas massif, Central Pyrenees-evidence for late orogenic extension prior to peak metamorphism. Geologie en Mijnbouw 68: 323-333.

Laumonier B, Guitard G (1986) Le Paléozoïque inférieur de la moitié orientale de la Zone Axiale des Pyrénées. Essai de synthèse. Comptes Rendus de l'Académie Sciences Paris 302: 473-478

Lescuyer JL, Cocherie A (1992) Datation sur monozircons des métadacites de Sériès: arguments pour un âge protérozoïque terminal des schistes X de la Montagne Noire (Massif central français). Comptes Rendus de l'Académie des Sciences 314: 10711077.

Linnemann U, Gerdes A, Drost K, Buschmann B (2007) The continuum between Cadomian orogenesis and opening of the Rheic Ocean: Constraints from LA-ICP-MS U-Pb zircon dating and analysis of plate-tectonic setting (Saxo-Thuringian zone, northeastern Bohemian Massif, Germany). In: Linnemann U, Nance RD, Kraft P, Zulauf G (eds.), The evolution of the Rheic Ocean: From Avalonian-Cadomian active margin to Alleghenian-Variscan collision: Geological Society of America Special Paper 423: 61-96. doi: 10.1130/2007.2423(03) 
Losantos M, Palau J, Carreras J, Druguet E, Santanach P, Cirés J (1997) Mapa geològic de Catalunya, Escala 1:25.000 Fulls: Roses 259-1-1, Cap de Creus, 259-2-1, Far de Roses 259-1-2. ICC Barcelona, España.

548 Ludwig KR (1998) On the treatment of concordant uranium-lead ages. Geochimica et Cosmochimica Acta 62; 665-676.

Ludwig KR (2001). Users Manual for Isoplot/Ex rev. 2.49. Berkeley Geochronology Center Special Publication No. 1a, 1-56.

Maurel O, Respaut JP, Monié P, Arnaud N, Brunel M (2004) U-Pb emplacement and 553 40Ar/39Ar cooling ages of the eastern Mont-Louis granite massif (eastern Pyrenees, France). Comptes Rendus Geosciences 336: 1091-1098.

Melleton J, Cocherie A, Faure M, Rossi P (2010) Precambrian protoliths and Early Paleozoic magmatism in the French Massif Central: U-Pb data and the North Gondwana connection in the west European Variscan belt. Gondwana Research 17: 13-25. doi: 10.1016/j.gr.2009.05.007

Mezger JE (2010) Cadomian, Ordovician and Variscan igneous events preserved in gneiss domes of the Central Pyrenean Axial Zone. 13. Symposium "Tektonik, Struktur- und Kristallingeologie" (TSK 13), Frankfurt, April 6-12, 2010. TSK 13 Conference abstracts and field guides, 40 .

Micheletti F, Barbey P, Fornelli A, Piccarreta G, Deloule E (2007). Latest Precambrian to Early Cambrian U-Pb zircon ages of augen gneisses from Calabria (Italy), with inference to the Alboran microplate in the evolution of the peri-Gondwana terranes.

567 Mingram B, Kröner A, Hegner E, Krentz O (2004) Zircon ages, geochemistry, and Nd 568 isotopic systematics of pre-Variscan orthogneisses from the Erzgebirge, Saxony (Germany), and geodynamic interpretation. International Journal of Earth Sciences 93: $706-727$. 
Muñoz J.A (1992) Evolution of a continental colision belt:ECORS-Pyrenees crustal balanced cross-section. In: Mc Clay KR (ed.), Thrust Tectonics, London: Chapman \& Hall. 235-246.

Muñoz JA, Vergés J, Martínez-Rius A, Fleta J, Cirés J, Casas JM, Sàbat F (1994) Mapa geológico de España (1:50.000): Ripoll ( $\mathrm{n}^{\circ}$ 256). ITGE Madrid, España.

Murphy JB, Pisarevsky·SA, Nance RD, Keppie JD (2004) Neoproterozoic-Early Paleozoic evolution of peri-Gondwanan terranes: implications for Laurentia-Gondwana connections. International Journal of Earth Sciences 93: 659-682. doi: $10.1007 / \mathrm{s} 00531-004-0412-9$

Nance RD, Gutiérrez-Alonso G, Keppie JD, Linneman, U, Murphy JB, Quesada C, Strahan RA. Woodcock NH (2010). Evolution of the Rheic Ocean. Gondwana Research 17: $194-222$.

Navidad M, Carreras J (1995) Pre-Hercynian magmatism in the eastern Pyrenees (Cap de Creus and Albera Massifs) and its geodynamical setting. Geologie en Mijnbouw: 74, $65-77$.

Navidad M, Carreras J (2002) El volcanismo de la base del Paleozoico Inferior del Canigó (Pirineos Orientales). Evidencias geoquímicas de la apertura de una cuenca continental. Geogaceta 32: 91-94.

Navidad M, Castiñeiras P, Casas JM, Liesa M, Fernández Suárez J, Barnolas A, Carreras J, Gil-Peña I (2010) Geochemical characterization and isotopic age of Caradocian magmatism in the northeastern Iberian Peninsula: Insights into the Late Ordovician evolution of the northern Gondwana margin. Gondwana Research 17: 325-337.

Neubauer F (2002) Evolution of late Neoproterozoic to early Paleozoic tectonic elements in Central and Southeast European Alpine mountain belts: review and synthesis. Tectonophysics 352: 87-103. doi: 10.1016/S0040-1951(02)00190-7 
Pearce JA, Harris NGW, Tindle AG (1984) Trace element discrimination diagrams for the tectonic interpretation of granitic rocks. Journal of Petrology 25: 956-983. doi:10.1093/petrology/25.4.956

600

Rodríguez-Alonso M D, Peinado M. López-Plaza M, Franco P, Carnicero A, Gonzalo JC (2004) Neoproterozoic-Cambrian synsedimentary magmatism in the Central Iberian Zone (Spain): geology, petrology and geodynamic significance. International Journal of Earth Sciences 93: 897-920.

603 Romer RL, Soler A (1995) U-Pb age and lead isotopic characterization of Au-bearing skarn 604 related to the Andorra granite. Mineralium Deposita 30: 374-383.

605

Rubio-Ordónez A, Gutiérrez-Alonso G, Valverde-Vaquero P, Cuesta A, Gallastegui G, 606 Gerdes A, Cárdenes V (2013) Arc-related Ediacaran magmatism along the northern margin of Gondwana: Geochronology and isotopic geochemistry from northern Iberia. Gondwana Research, in press. doi: 10.1016/j.gr.2013.09.016

Sambridge MS, Compston W (1994) Mixture modeling of multi-component data sets with application to ion-probe zircon ages. Earth and Planetary Science Letters 128: 373390.

612 Santanach PF (1972a) Sobre una discordancia en el Paleozoico inferior de los Pirineos orientales. Acta Geológica Hispánica 7: 129-132.

614 Santanach PF (1972b) Estudio tectónico del Paleozoico inferior del Pirineo entre la Cerdaña y el río Ter. Acta Geológica Hispánica 7: 44-49.

616 Simancas JF, Expósito I, Azor A, Martínez Poyatos D, González Lodeiro F (2004) From the 617 Cadomian orogenesis to the Early Paleozoic Variscan rifting in Southwest Iberia. $618 \quad$ Journal of Iberian Geology 30: 53-71.

619 Talavera C, Montero P, Martínez Poyatos D, Williams IS (2012) Ediacaran to Lower 620 Ordovician age for rocks ascribed to the Schist-Graywacke Complex (Iberian Massif, 

Research 22: 928-942.

623 Taylor SR, McLennan SM (1985) The continental crust: its composition and evolution. Blackwell, Oxford.

Teipel U, Eichhorn R, Loth G, Rohrmüller J, Höll R, Kennedy A (2004) U-Pb SHRIMP and $\mathrm{Nd}$ isotopic data from the western Bohemian Massif (Bayerischer Wald, Germany): Implications for Upper Vendian and Lower Ordovician magmatism. International Journal of Earth Sciences 93: 782-801.

Williams IS, Fiannacca P, Cirrincione R, Pezzino A (2012) Peri-Gondwanan origin and early geodynamic history of NE Sicily: A zircon tale from the basement of the Peloritani Mountains. Gondwana Research 22: 855-865. doi: 10.1016/j.gr.2011.12.007

Winchester JA, Floyd PA (1977) Geochemical discrimination of different magma series and their differentiation products using immobile elements. Chemical Geology 20: 325343.

Yilmaz Şahin S, Aysal N, Güngör Y, Peytcheva I, Neubauer F (2013) Geochemistry and U$\mathrm{Pb}$ zircon geochronology of metagranites in Istranca (Strandja) Zone, NW Pontides, Turkey: Implications for the geodynamic evolution of Cadomian orogeny. Gondwana

Zlatkin O, Avigad D, Gerdes A (2013) Evolution and provenance of Neoproterozoic basement and Lower Paleozoic siliciclastic cover of the Menderes Massif (western

643 Zwart HJ (1979) The geology of the Central Pyrenees. Leidse Geologische Mededelingen 50, 
647 Table 1. Geochronological data of samples under study and those of (1) Cocherie et al. (2005)

648 and (2) Castiñeiras et al. (2008).

649

650 Table 2. Whole-rock geochemistry of the samples from the Canigó and Cap de Creus massifs.

651

652 Table 3. Sr-Nd isotopic data for samples.

653

654 FIGURE CAPTIONS

655 Figure 1. Simplified geological map of the Eastern Pyrenees with the location of the areas 656 under study.

658 Figure 2. Synthetic stratigraphic columns of the pre-Upper Ordovician rocks of the Canigó

659 and Cap de Creus massifs with the location of the samples and previous geochronological

660 data: (1) Cocherie et al. (2005), (2) Castiñeiras et al. (2008). Data from Guitard (1970),

661 Santanach (1972b), Ayora and Casas (1986) and Losantos et al. (1997).

662

663 Figure. 3. Schematic geological maps with the location of the samples and previous

664 geochronological data: (a) Southern flank of the Canigó massif (GRA-1, Cocherie et al. 2005;

665 NU-3, Castiñeiras et al. 2008); (b) Cap de Creus massif (CC-05-02 and CC-05-07, Castiñeiras 666 et al. 2008). Data from Guitard (1970), Ayora and Casas (1986), Cirés et al. (1994), Muñoz et 667 al. (1994) and Carreras and Druguet (2013).

668

669 Figure 4. (a) Classification diagram $\mathrm{Zr} / \mathrm{TiO}_{2}$ versus $\mathrm{Nb} / \mathrm{Y}$ (Winchester and Floyd 1977); (b)

670 classification and character of the magma series in the Th-Co diagram (Hastie et al. 2007). 
672 Figure 5. (a) Multi-element diagram normalized to ORG values after Harris et al. (1986) and

673 (b) chondrite-normalized REE diagram for the rocks (normalization values after Taylor and

674 McLennan 1985)

675

676 Figure 6. Tectonic setting discrimination diagram after Harris et al. (1986).

677

678 Figure 7. (a) eNd versus age diagram and (b) $\square \mathrm{Nd}$ versus $\square \mathrm{Sr}$ diagram for the analyzed 679 samples. Depleted mantle evolution calculated according to DePaolo (1981).

680

681 Figure 8. Cathodoluminescence images for selected zircons from the analyzed samples.

682

683 Figure 9. Wetherill concordia diagrams for the Canigó samples (a) TG-07-01, (b) TG-07-02

684 and (c) TG-07-03. Error ellipses are plotted at $2 \square$.

685

686 Figure 10. U-Pb results for the Cap de Creus samples; (a) (b) and (d) Wetherill concordia 687 diagrams for samples CC-08-01, CC-08-07 and CC-08-08, (c) probability density plot 688 showing the results of the Sambridge and Compston (1994) algorithm for sample CC-08-07 689 (see text for explanation). Error ellipses are plotted at $2 \square$.

690

691

ONLINE RESOURCES

692

693 Online Resource 1. Details of the analytical procedure.

694

695 Online Resource 2. Results of the zircon analyses.

696 
Online Resource 1 Casas et al
Click here to download Electronic Supplementary Material: Online Resource 1.doc

Online Resource 1 Casas et al
Click here to download Electronic Supplementary Material: Online Resource 1.doc

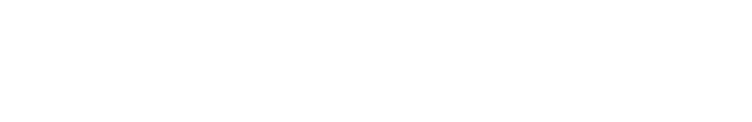

(1) 
Online Resource 2 Casas et al
Click here to download Electronic Supplementary Material: Online Resource 2.xls

Online Resource 2 Casas et al
Click here to download Electronic Supplementary Material: Online Resource 2.xls 


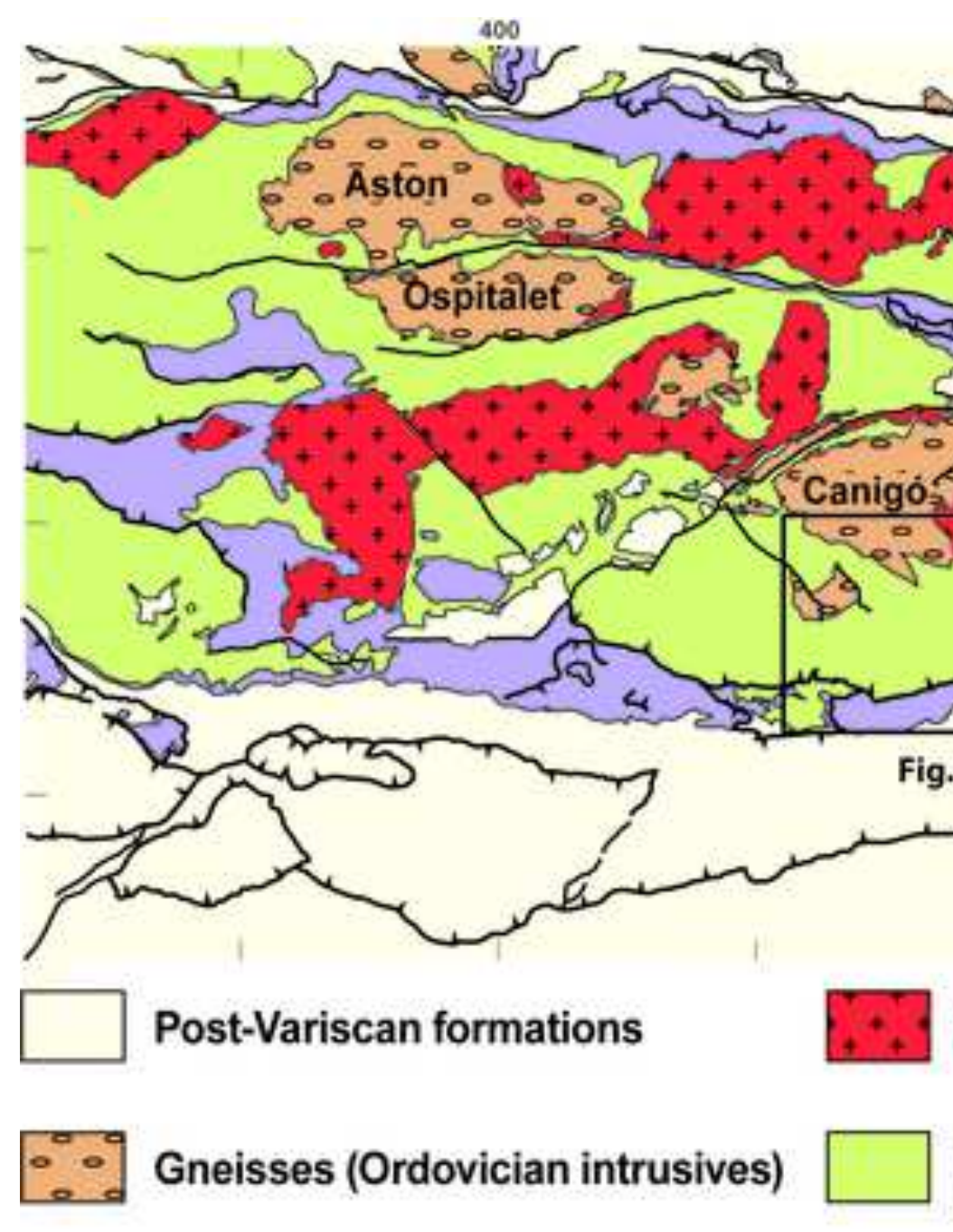

Upper Neoproterozoic
and Cambro-Ordovician

Upper Neoproterozoic
and Cambro-Ordovician

450
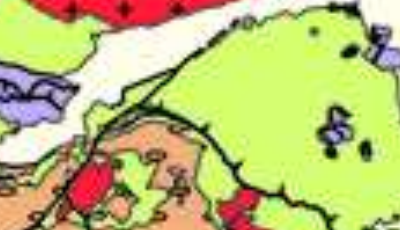

\$. Roc de Frausa

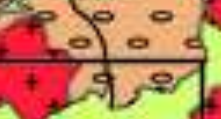

g. 3a

Variscan Granitoids
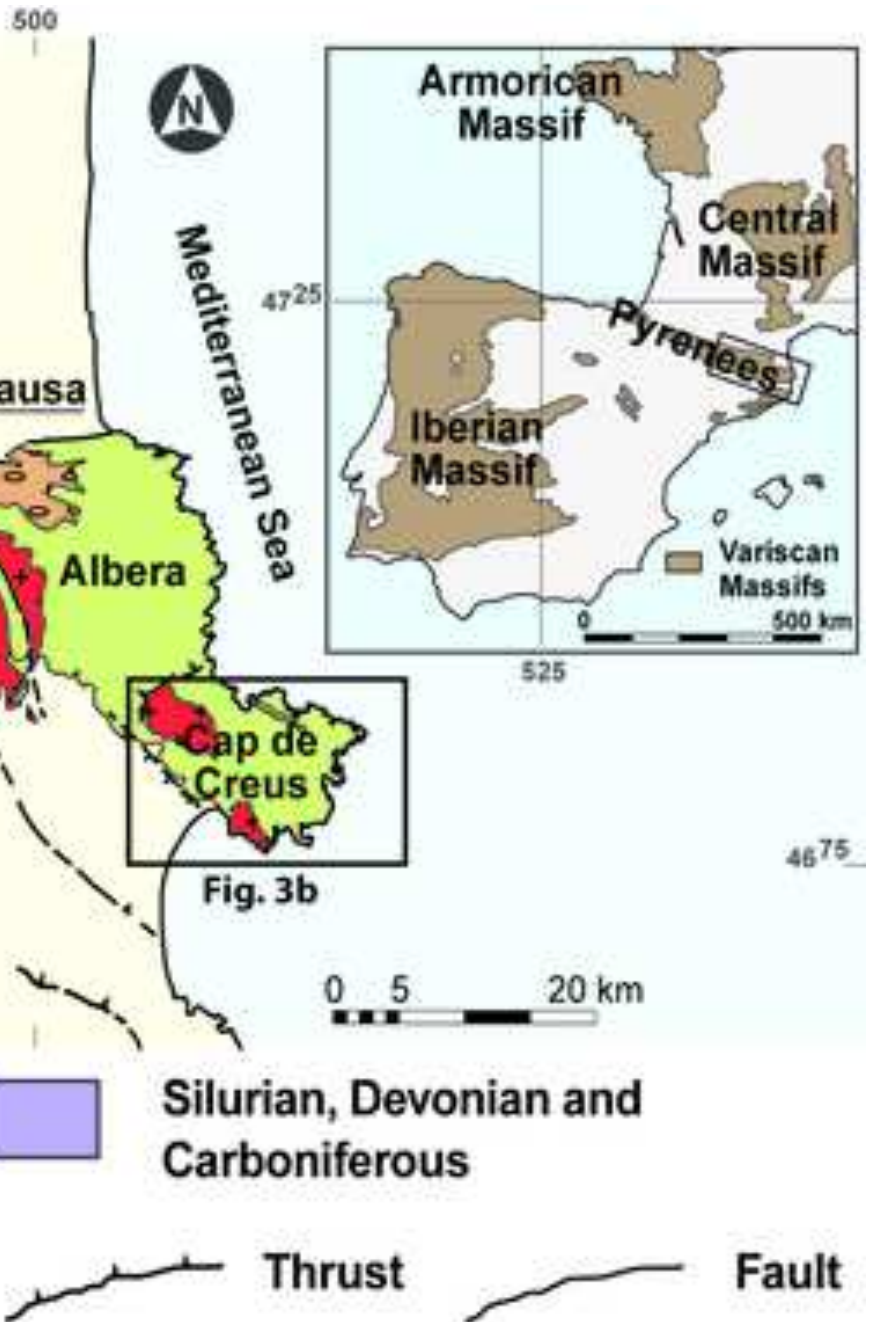

Fault 


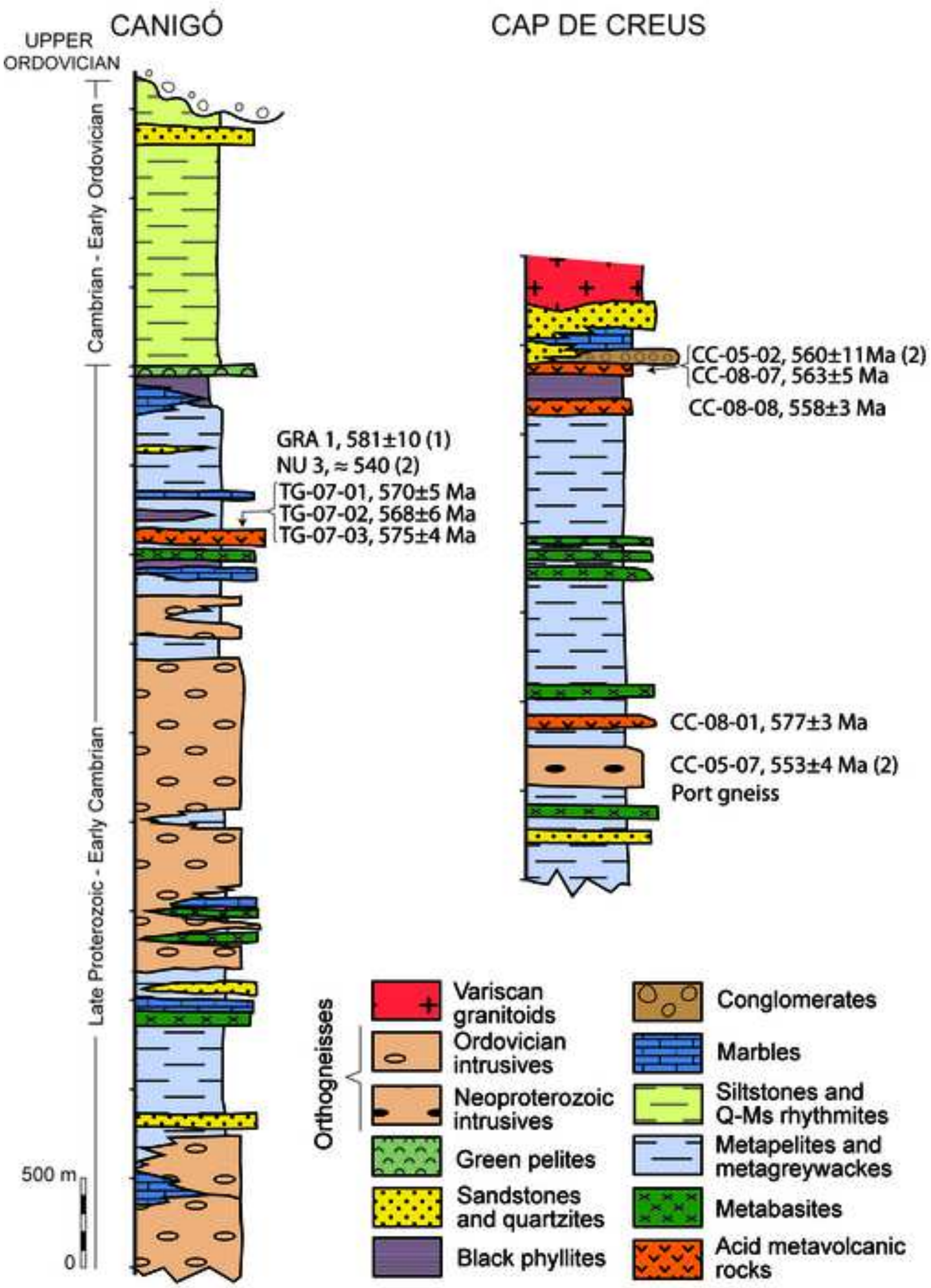


Click here to download high resolution image

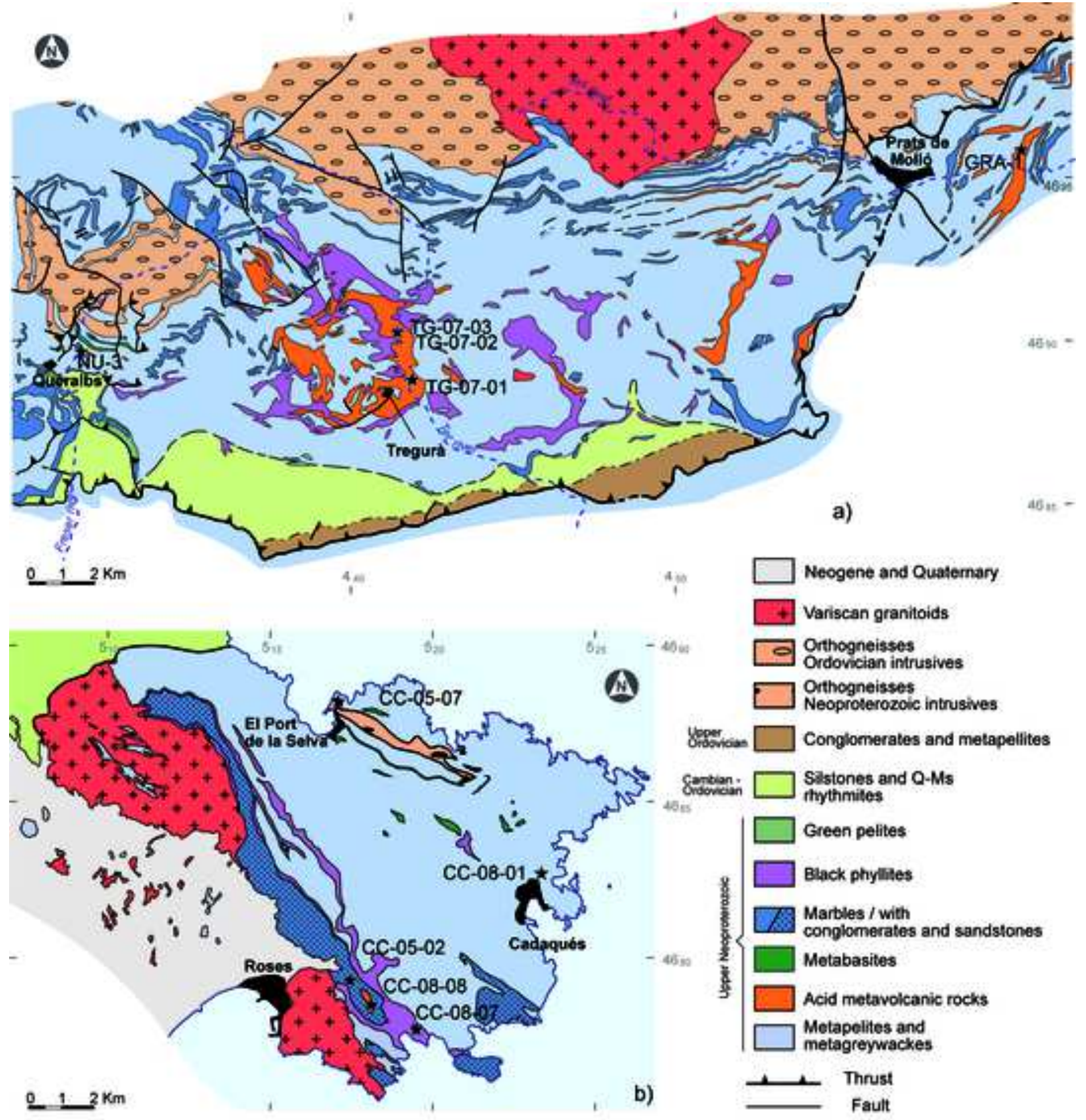




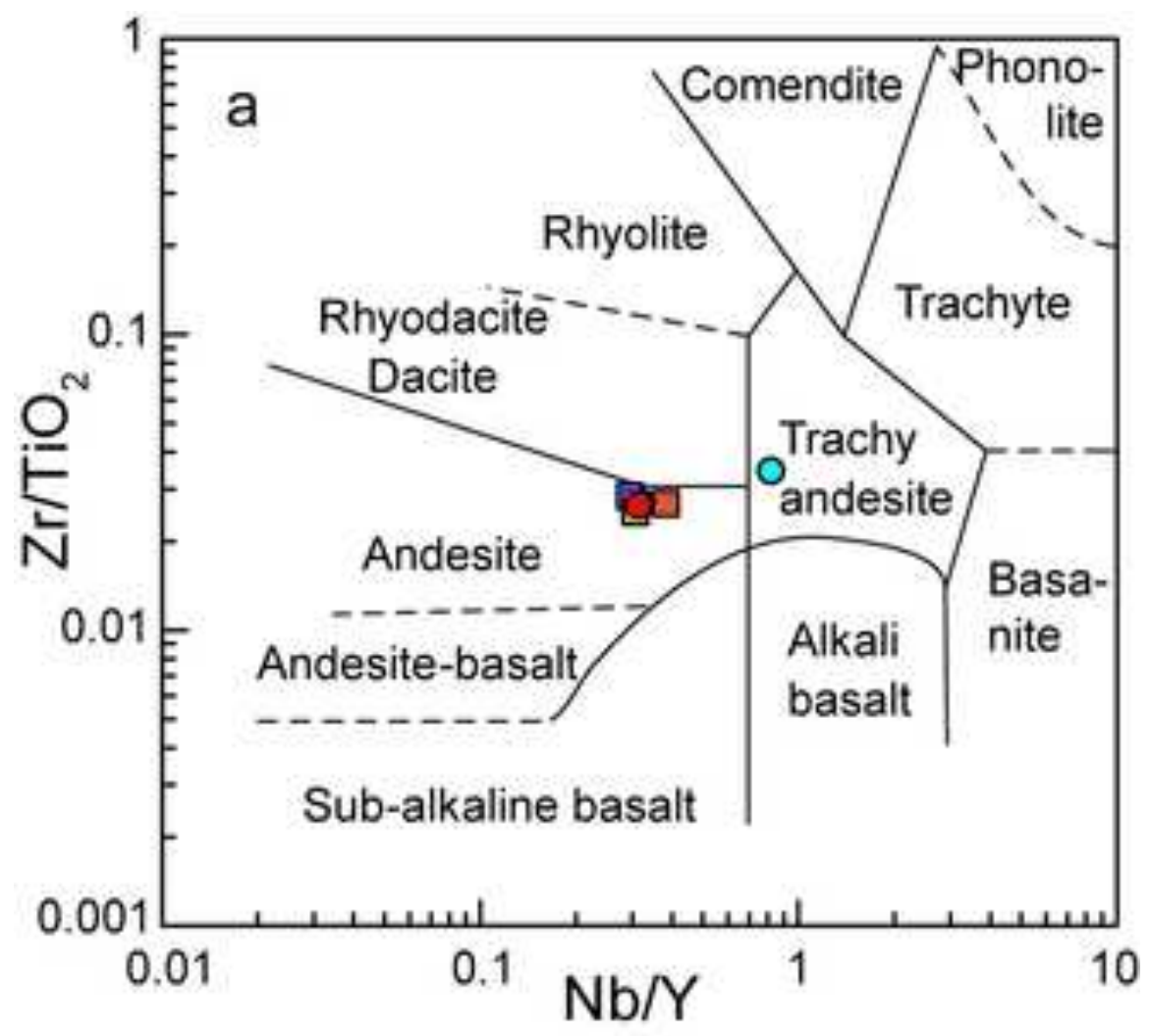
O CC-08-01 $\square$ TG-07-01
- CC-08-07 $\square$ TG-07-02
O CC-08-08 $\square$ TG-07-03

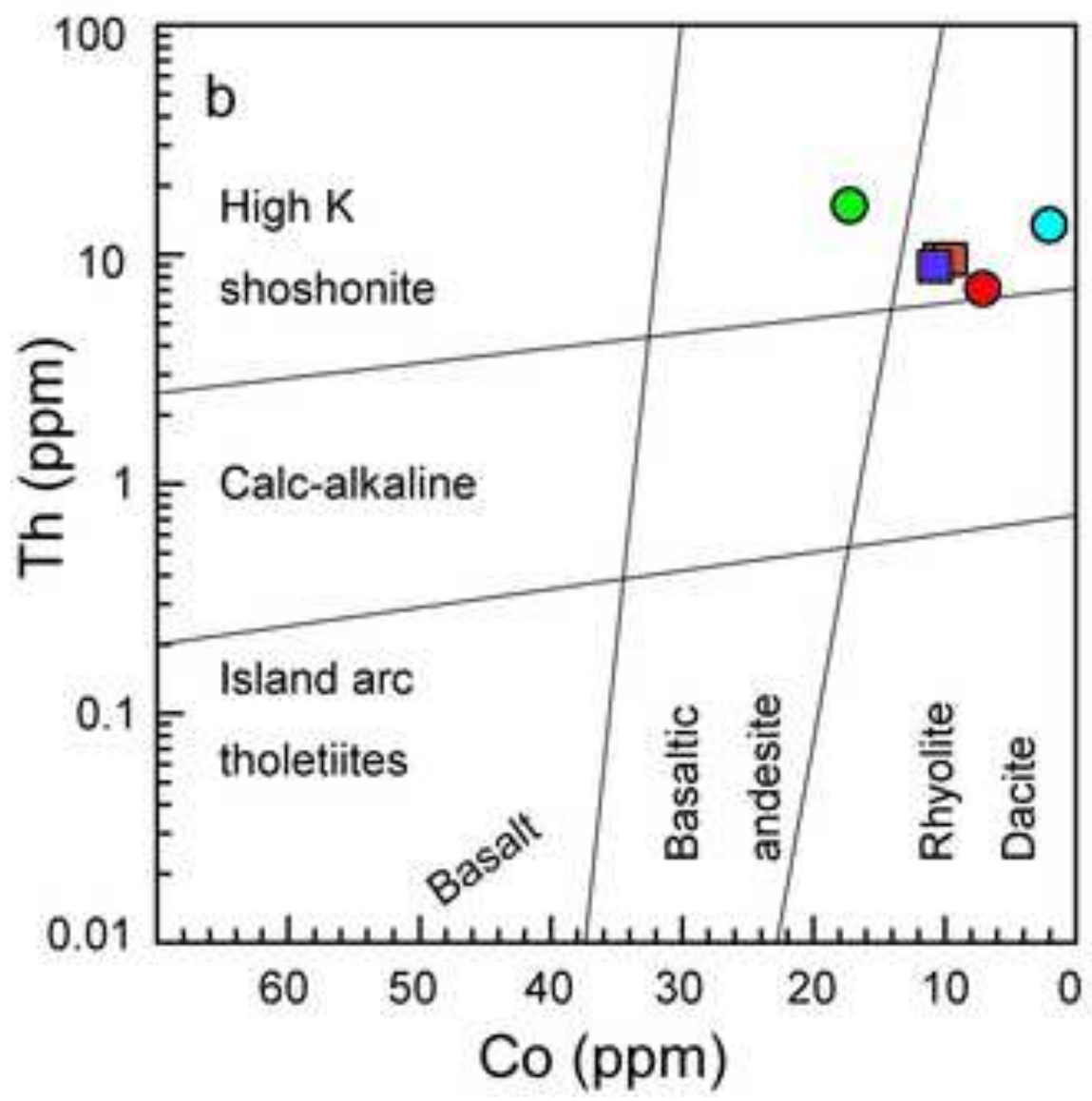


Figure 5

Click here to download high resolution image
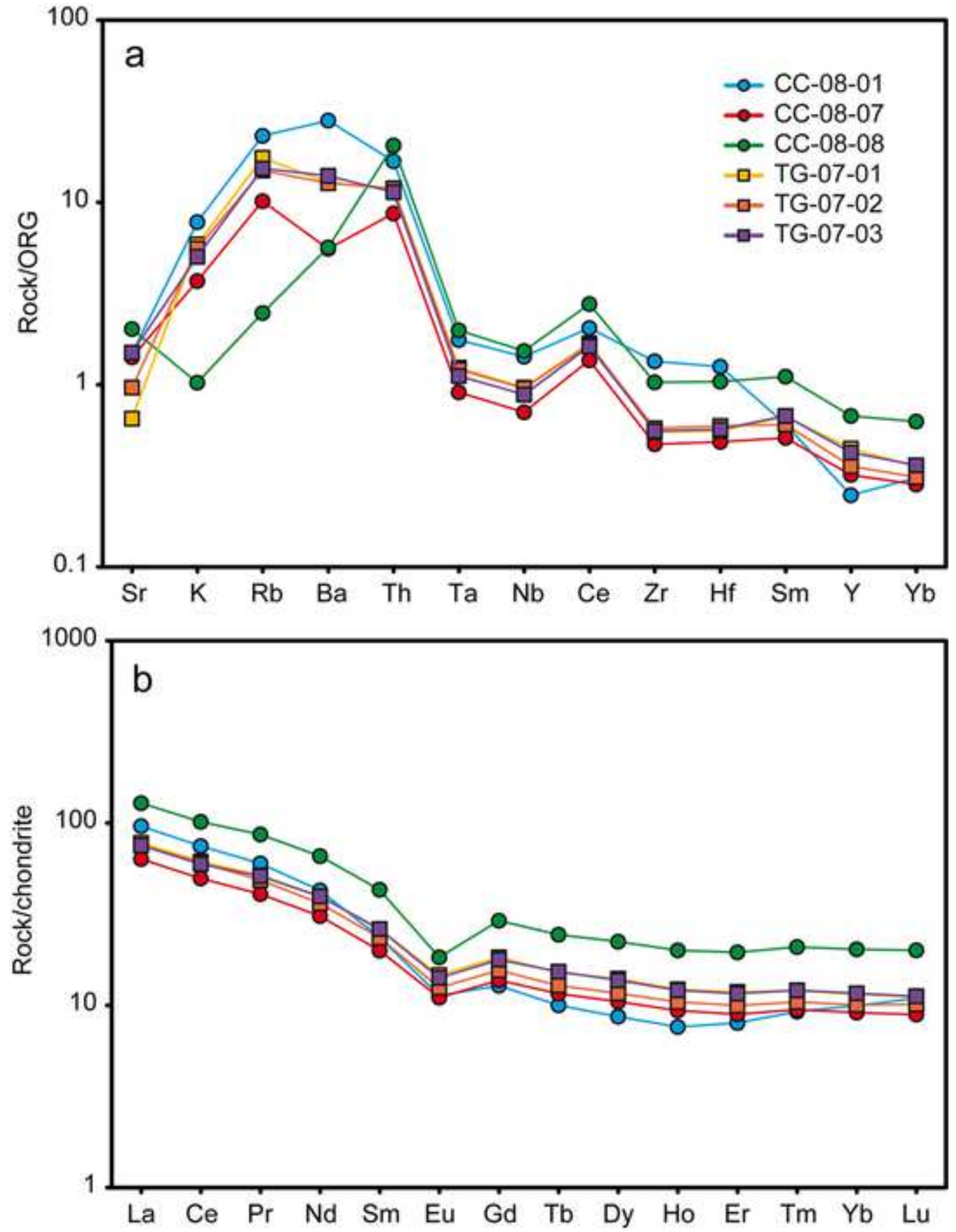
$\mathrm{Rb} / 30$

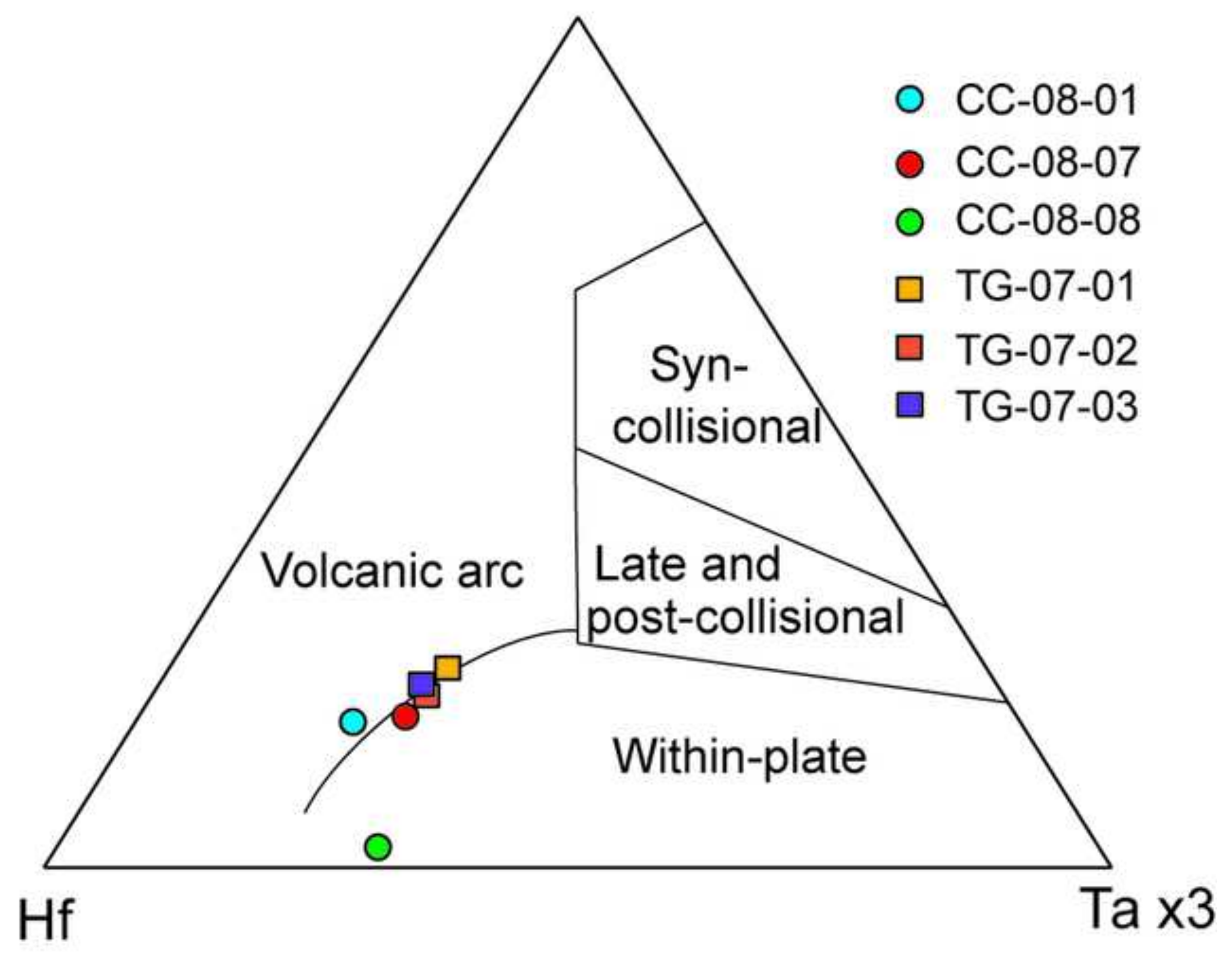



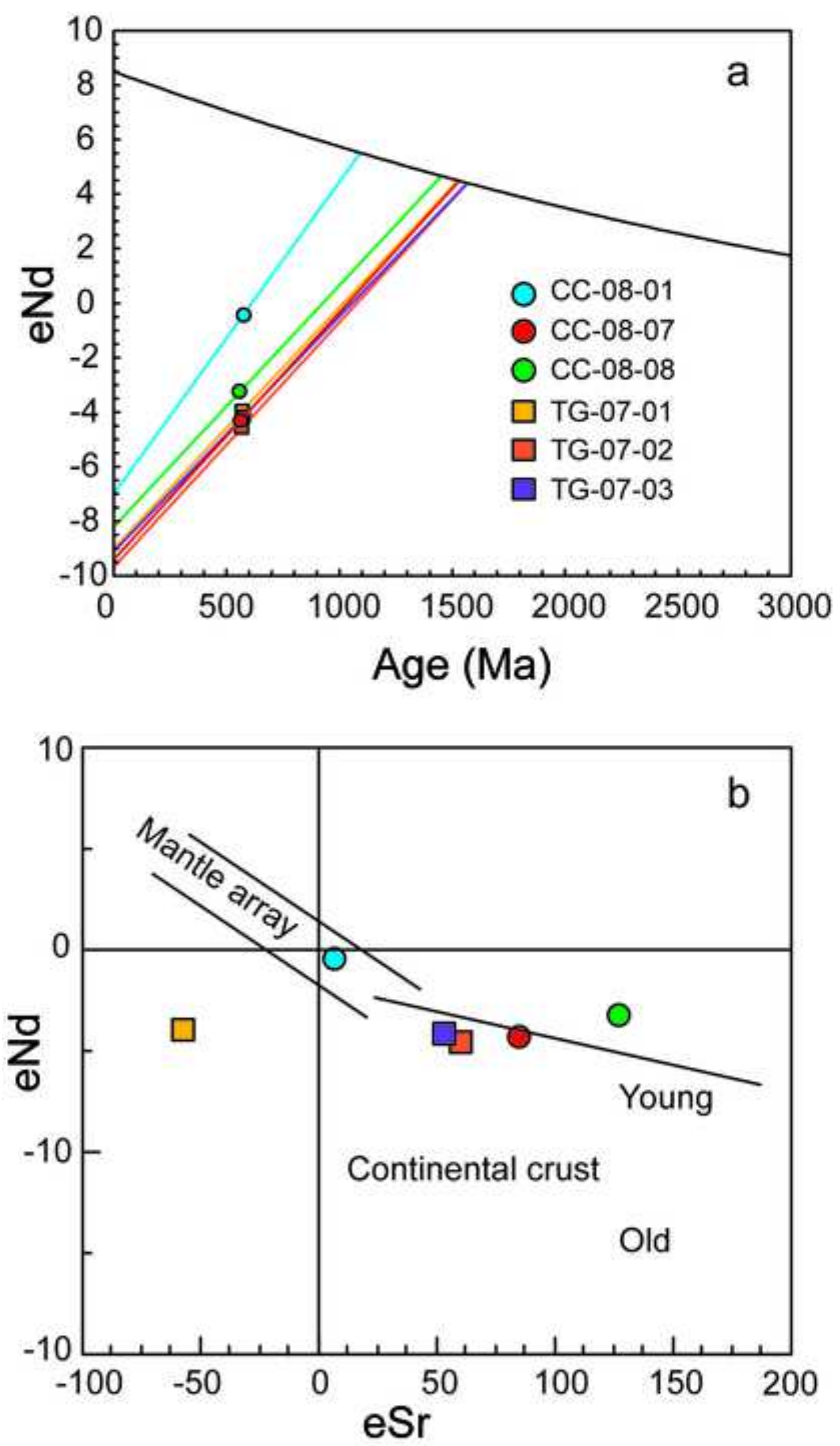
Click here to download high resolution image

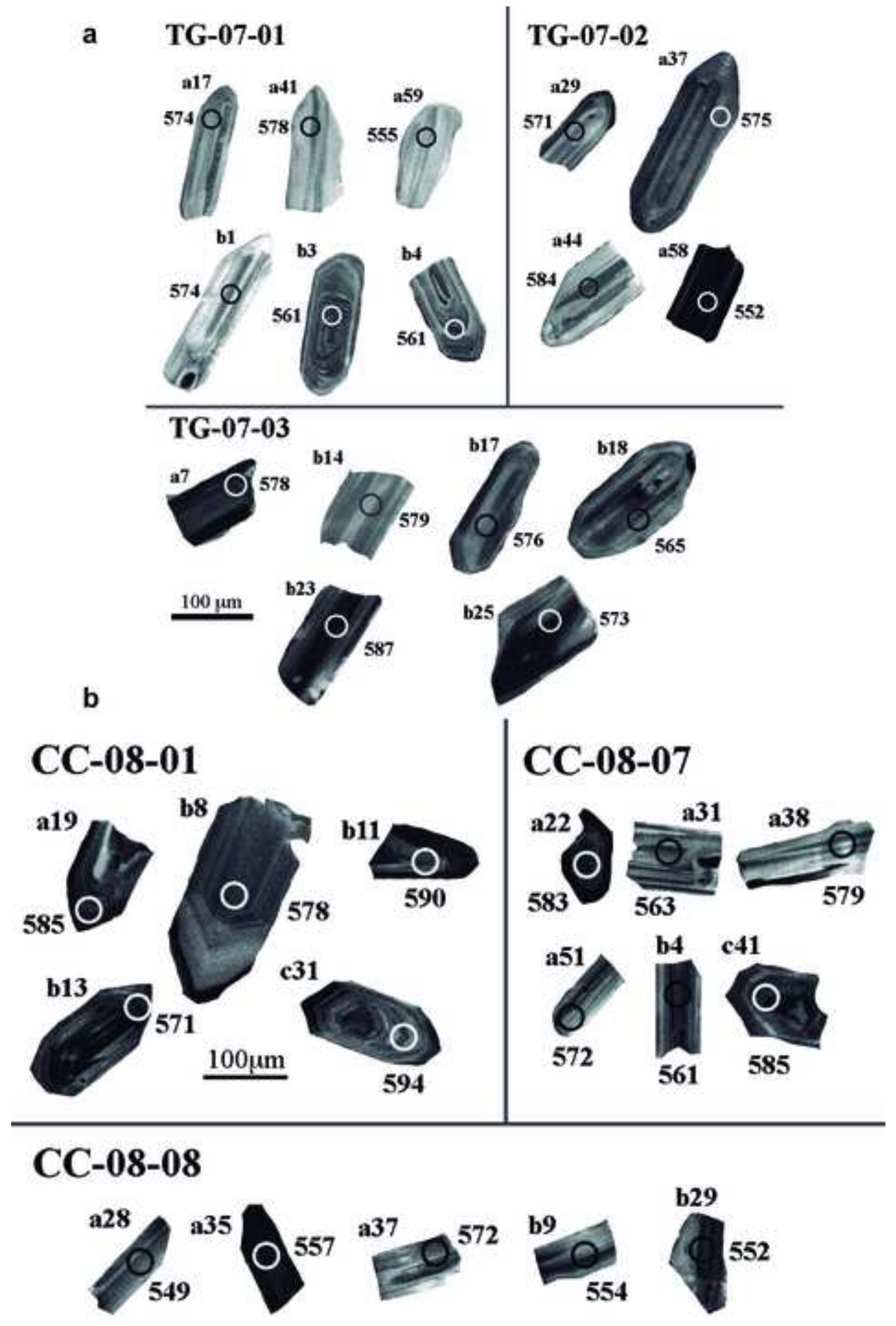


Figure 9

Click here to download high resolution image
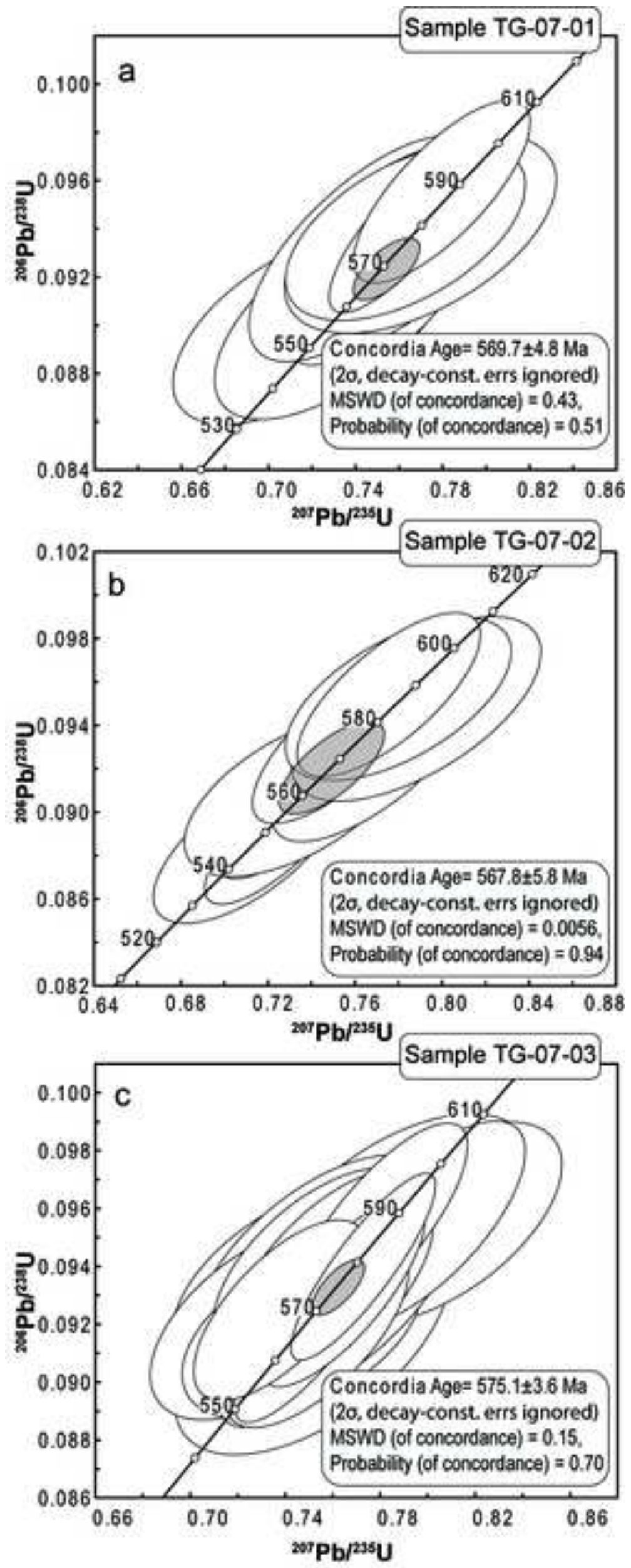
Click here to download high resolution image
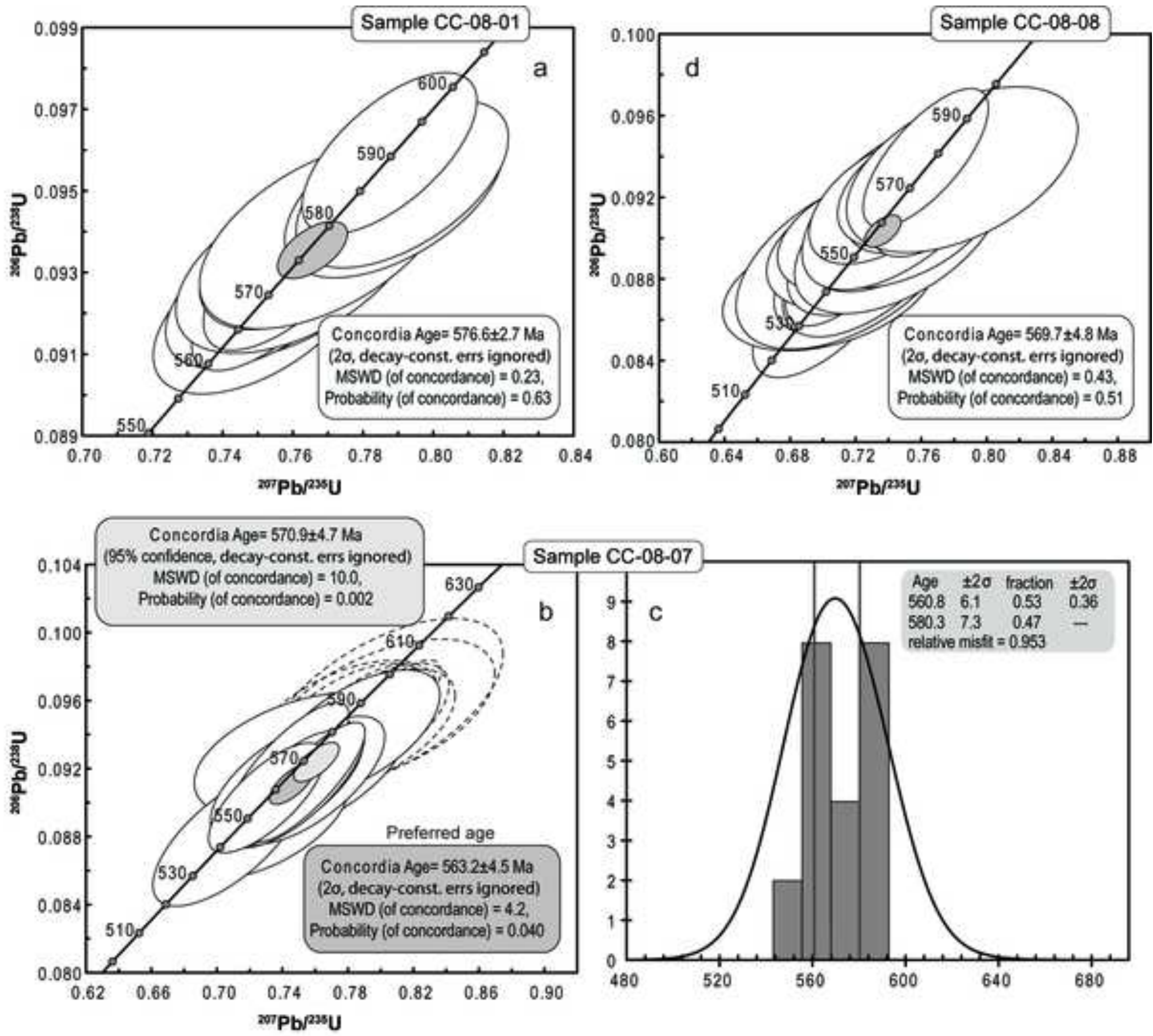


\begin{tabular}{|c|c|c|c|c|c|c|}
\hline Sample & Reference & Rock type & Age & Sampling site & $\mathbf{X}$ & $\mathbf{Y}$ \\
\hline GRA I & $(1)$ & Acid metatuff & $581 \pm 10(\mathrm{U}-\mathrm{Pb}$ SHRIMP) & $\begin{array}{l}\text { Canigó massif. "Sitges" lapillis, D15 road left bank of Tec river, } \\
\text { St. Eloi oratory. }\end{array}$ & 615440 & 1711444 \\
\hline NU 3 & (2) & Acid metatuff & $\approx 540(\mathrm{U}-\mathrm{Pb}$ SHRIMP) & Canigó massif. Queralbs-La Farga. & 431759 & 4689782 \\
\hline RF 3 & $(2)$ & Acid metatuff & $548 \pm 8(\mathrm{U}-\mathrm{Pb}$ SHRIMP) & Roc de Frausa massif. Les Illes. Mas Quintassos. & 481970 & 4696770 \\
\hline $\mathrm{RF} 4$ & (2) & Mas Blanc gneiss & $560 \pm 7$ (U-Pb SHRIMP) & Roc de Frausa massif. Mas Blanc. & 482058 & 4696535 \\
\hline CC 2 & (2) & Acid metatuff & $560 \pm 7(\mathrm{U}-\mathrm{Pb}$ SHRIMP) & Cap de Creus massif. Roses. Coll d'Alzeda. & 517736 & 4679447 \\
\hline $\mathrm{CC} 7$ & (2) & Port gneiss & $553 \pm 4(\mathrm{U}-\mathrm{Pb}$ SHRIMP) & Cap de Creus massif. Port de la Selva quarry. & 517582 & 4687795 \\
\hline TG-07-01 & This work & Ignimbrite & $570 \pm 5$ (LA-ICP-MS) & Canigó massif. Tregurà. GIV5284 road, left bank of Ter river. & 442098 & 4688717 \\
\hline TG-07-02 & This work & Ignimbrite & $568 \pm 5$ (LA-ICP-MS) & Canigó massif. Tregurà. GIV5284 road, left bank of Ter river. & 441882 & 4689874 \\
\hline TG-07-03 & This work & Ignimbrite & $575 \pm 4$ (LA-ICP-MS) & Canigó massif. Tregurà. GIV5284 road, right bank of Ter river. & 441683 & 4690200 \\
\hline CC-08-01 & This work & Acid metatuff & $577 \pm 3$ (LA-ICP-MS) & Cap de Creus massif. Cadaqués. S'Alqueria Petita. & 523965 & 4682985 \\
\hline CC-08-07 & This work & Ignimbrite & $563 \pm 5$ (LA-ICP-MS) & Cap de Creus massif. Cala Montjoi, Torre Morisca. & 519401 & 4678026 \\
\hline CC-08-08 & This work & Acid metatuff & $558 \pm 3$ (LA-ICP-MS) & Cap de Creus massif. Roses-Cadaqués road. Mas de la Torre. & 518226 & 4677333 \\
\hline
\end{tabular}

Table 1 
CC-08-01 CC-08-07 CC-08-08 TG-07-01 TG-07-02 TG-07-03

\begin{tabular}{|c|c|c|c|c|c|c|}
\hline $\mathrm{SiO}_{2}$ & 69.25 & 58.98 & 55.79 & 66.86 & 68.61 & 55.57 \\
\hline $\mathrm{TiO}_{2}$ & 1.33 & 0.61 & 1.30 & 0.75 & 0.73 & 0.67 \\
\hline $\mathrm{Al}_{2} \mathrm{O}_{3}$ & 14.28 & 9.74 & 19.00 & 12.84 & 12.18 & 11.71 \\
\hline $\mathrm{Fe}_{2} \mathrm{O}_{3(\mathrm{~T})}$ & 3.71 & 4.31 & 7.64 & 5.03 & 4.52 & 4.34 \\
\hline $\mathrm{MnO}$ & 0.03 & 0.15 & 0.10 & 0.12 & 0.09 & 0.13 \\
\hline $\mathrm{MgO}$ & 1.08 & 3.72 & 3.21 & 2.38 & 1.98 & 1.85 \\
\hline $\mathrm{CaO}$ & 1.07 & 11.30 & 1.33 & 1.94 & 2.40 & 10.35 \\
\hline $\mathrm{Na}_{2} \mathrm{O}$ & 2.13 & 2.14 & 7.54 & 2.58 & 2.59 & 2.48 \\
\hline $\mathrm{K}_{2} \mathrm{O}$ & 3.12 & 1.48 & 0.41 & 2.35 & 2.23 & 2.01 \\
\hline $\mathrm{P}_{2} \mathrm{O}_{5}$ & 0.17 & 0.17 & 0.37 & 0.25 & 0.20 & 0.25 \\
\hline LOI & 3.22 & 7.46 & 2.66 & 3.56 & 3.44 & 9.68 \\
\hline Total & 99.38 & 100.05 & 99.34 & 98.64 & 98.97 & 99.05 \\
\hline $\mathrm{Ba}$ & 1405 & 278 & 283 & 643 & 637 & 697 \\
\hline $\mathrm{Be}$ & 1.8 & $<$ LD & $<\mathrm{LD}$ & 1.8 & 1.6 & $<\mathrm{LD}$ \\
\hline Co & 2.0 & 7.7 & 17 & 10 & 10 & 11 \\
\hline $\mathrm{Cr}$ & 145 & 58 & 83 & 75 & 71 & 61 \\
\hline $\mathrm{Cu}$ & 24 & 10 & 69 & 26 & 17 & 20 \\
\hline $\mathrm{Ga}$ & 19 & 12 & 12 & 17 & 15 & 15 \\
\hline $\mathrm{Hf}$ & 11 & 4.4 & 9.3 & 5.0 & 5.3 & 5.1 \\
\hline $\mathrm{Nb}$ & 14 & 7.0 & 15 & 10 & 10 & 8.8 \\
\hline $\mathrm{Ni}$ & 11 & 22 & 33 & 29 & 27 & 26 \\
\hline $\mathrm{Rb}$ & 93 & 41 & 10 & 70 & 60 & 61 \\
\hline $\mathrm{Sr}$ & 148 & 141 & 201 & 65 & 96 & 149 \\
\hline $\mathrm{Ta}$ & 1.2 & 0.6 & 1.4 & 0.9 & 0.8 & 0.8 \\
\hline Th & 13 & 6.9 & 16 & 10 & 10 & 9.1 \\
\hline$U$ & 3.8 & 1.9 & 4.1 & 2.4 & 2.2 & 2.5 \\
\hline V & 137 & 57 & 113 & 77 & 75 & 71 \\
\hline Y & 17 & 22 & 47 & 31 & 25 & 30 \\
\hline $\mathrm{Zn}$ & 28 & 57 & 69 & 71 & 34 & 59 \\
\hline $\mathrm{Zr}$ & 457 & 160 & 350 & 186 & 195 & 189 \\
\hline La & 35 & 23 & 47 & 29 & 28 & 28 \\
\hline $\mathrm{Ce}$ & 71 & 48 & 97 & 59 & 58 & 57 \\
\hline $\mathrm{Pr}$ & 8.2 & 5.6 & 11.8 & 7.1 & 6.6 & 7.0 \\
\hline $\mathrm{Nd}$ & 30 & 22 & 47 & 28 & 26 & 28 \\
\hline $\mathrm{Sm}$ & 5.4 & 4.6 & 10 & 6.0 & 5.4 & 6.0 \\
\hline $\mathrm{Eu}$ & 0.98 & 0.96 & 1.59 & 1.27 & 1.09 & 1.23 \\
\hline $\mathrm{Gd}$ & 3.9 & 4.2 & 8.9 & 5.6 & 4.8 & 5.4 \\
\hline $\mathrm{Tb}$ & 0.58 & 0.67 & 1.41 & 0.88 & 0.74 & 0.89 \\
\hline Dy & 3.3 & 4.0 & 8.5 & 5.3 & 4.4 & 5.2 \\
\hline $\mathrm{Ho}$ & 0.65 & 0.80 & 1.70 & 1.04 & 0.89 & 1.03 \\
\hline $\mathrm{Er}$ & 2.0 & 2.2 & 4.9 & 2.9 & 2.5 & 2.9 \\
\hline $\mathrm{Tm}$ & 0.33 & 0.34 & 0.74 & 0.43 & 0.37 & 0.43 \\
\hline $\mathrm{Yb}$ & 2.5 & 2.3 & 5.0 & 2.8 & 2.5 & 2.9 \\
\hline Lu & 0.42 & 0.34 & 0.76 & 0.42 & 0.39 & 0.43 \\
\hline
\end{tabular}


Oxides expressed as \%wt, minor and rare earth elements as ppm

$\mathrm{Fe}_{2} \mathrm{O}_{3(\mathrm{~T})}$ expressed as total iron

LOI: Lost on ignition

<LD: below detection limit 


\begin{tabular}{ccccccccccc}
\hline Samples & $\mathrm{Sm} / \mathrm{Nd}$ & $\mathrm{Rb} / \mathrm{Sr}$ & $\left({ }^{147} \mathrm{Sm} /{ }^{144} \mathrm{Nd}\right)\left({ }^{87} \mathrm{Sr} /{ }^{86} \mathrm{Sr}\right)_{\mathrm{P}}\left({ }^{87} \mathrm{Sr} /{ }^{86} \mathrm{Sr}\right)_{560}\left({ }^{143} \mathrm{Nd} /{ }^{144} \mathrm{Nd}\right)_{\mathrm{P}}\left({ }^{143} \mathrm{Nd} /{ }^{144} \mathrm{Nd}\right)_{56 \mathrm{C}} \mathrm{eNd}{ }_{560}$ & $\mathrm{eSr}$ \\
\hline TG-07-01 & 0.21 & 1.08 & 0.1284 & 3.121498 & 0.699797 & 0.512181 & 0.511709 & -4.0 & -57 & 1.52 \\
$\mathrm{TG}-07-02$ & 0.21 & 0.62 & 0.1275 & 1.806548 & 0.708024 & 0.512146 & 0.511679 & -4.6 & 59 & 1.56 \\
$\mathrm{TG}-07-03$ & 0.22 & 0.41 & 0.1301 & 1.185574 & 0.707653 & 0.512175 & 0.511698 & -4.3 & 54 & 1.55 \\
$\mathrm{CC}-08-01$ & 0.18 & 0.63 & 0.1083 & 1.812453 & 0.704474 & 0.512281 & 0.511884 & -0.6 & 9 & 1.12 \\
$\mathrm{CC}-08-07$ & 0.21 & 0.29 & 0.1266 & 0.834941 & 0.709730 & 0.512159 & 0.511695 & -4.3 & 84 & 1.52 \\
$\mathrm{CC}-08-08$ & 0.21 & 0.05 & 0.1284 & 0.141754 & 0.712765 & 0.512223 & 0.511752 & -3.2 & 127 & 1.45 \\
\hline
\end{tabular}


Table 2. Sr - Nd of Cadomian acid rocks

\begin{tabular}{c}
\hline Age (Ma) \\
\hline 570 \\
568 \\
575 \\
577 \\
571 \\
558 \\
\hline
\end{tabular}

